\title{
Voorbereiding en aansluiting met het vervolgonderwijs en de arbeidsmarkt
}

Citation for published version (APA):

Sijbers, E., Meng, C., \& Allen, J. (2016). Voorbereiding en aansluiting met het vervolgonderwijs en de arbeidsmarkt. ROA. ROA Technical Reports No. 002 https://doi.org/10.26481/umarot.2016002

Document status and date:

Published: 01/01/2016

DOI:

10.26481/umarot.2016002

Document Version:

Publisher's PDF, also known as Version of record

\section{Please check the document version of this publication:}

- A submitted manuscript is the version of the article upon submission and before peer-review. There can be important differences between the submitted version and the official published version of record.

People interested in the research are advised to contact the author for the final version of the publication, or visit the DOI to the publisher's website.

- The final author version and the galley proof are versions of the publication after peer review.

- The final published version features the final layout of the paper including the volume, issue and page numbers.

Link to publication

\footnotetext{
General rights rights.

- You may freely distribute the URL identifying the publication in the public portal. please follow below link for the End User Agreement:

www.umlib.nl/taverne-license

Take down policy

If you believe that this document breaches copyright please contact us at:

repository@maastrichtuniversity.nl

providing details and we will investigate your claim.
}

Copyright and moral rights for the publications made accessible in the public portal are retained by the authors and/or other copyright owners and it is a condition of accessing publications that users recognise and abide by the legal requirements associated with these

- Users may download and print one copy of any publication from the public portal for the purpose of private study or research.

- You may not further distribute the material or use it for any profit-making activity or commercial gain

If the publication is distributed under the terms of Article $25 \mathrm{fa}$ of the Dutch Copyright Act, indicated by the "Taverne" license above, 


\section{Voorbereiding en aansluiting met het vervolgonderwijs en de arbeidsmarkt}

Eveline Sijbers

Christoph Meng

Jim Allen

\section{ROA Technical Report}

ROA-TR-2016/2

Researchcentrum voor Onderwijs en Arbeidsmarkt | ROA

Research Centre for Education and the Labour Market | ROA 


\title{
Voorbereiding en aansluiting met het vervolgonderwijs en de arbeidsmarkt
}

\author{
Eveline Sijbers \\ Christoph Meng \\ Jim Allen
}

ROA-TR-2016/2

April 2016

Research Centre for Education and the Labour Market Maastricht University

P.O. Box 616, 6200 MD Maastricht, The Netherlands

$\mathrm{T}+31433883647 \mathrm{~F}+31433884914$

secretary-roa-sbe@maastrichtuniversity.nl

www.roa.nl 


\section{INHOUD}

01 Inleiding

02 Data

03 Aansluiting en voorbereiding op vervolgopleiding 5

$\begin{array}{ll}3.1 \mathrm{vmbo} \text { naar mbo } & 6\end{array}$

3.2 havo/vwo naar hbo/wo 12

04 Aansluiting en voorbereiding op huidige functie 19

$\begin{array}{ll}4.1 \text { mbo naar arbeidsmarkt } & 20\end{array}$

$\begin{array}{ll}4.2 \text { hbo naar arbeidsmarkt } & 30\end{array}$

05 Verschillen naar achtergrondkenmerken $\quad 39$

06 Conclusies $\quad 43$

$\begin{array}{ll}\text { Literatuur } & 45\end{array}$

$\begin{array}{lr}\text { Bijlagen } & 47\end{array}$ 



\section{1 \\ INLEIDING}

Jongeren voorbereiden op een vervolgopleiding dan wel op de intrede op de arbeidsmarkt behoort tot de centrale rol die het onderwijs dient te vervullen. Naar aanleiding van het in 2015 verschenen rapport "Schoolverlaters tussen onderwijs en arbeidsmarkt 2014" is een discussie ontstaan over de betekenis van een aantal indicatoren zoals gemeten in de schoolverlatersonderzoeken, die in het kader van het SchoolverlatersInformatiesysteem van het Researchcentrum voor Onderwijs en Arbeidsmarkt (ROA) uitgevoerd worden. Zo werd geconstateerd dat schoolverlaters van het vmbo meestal tevreden waren over de aansluiting tussen de gevolgde opleiding en hun vervolgopleiding, terwijl ze zich tamelijk kritisch hebben getoond voor wat betreft de mate waarin hun opleiding een goede voorbereiding bood op het vervolgonderwijs. Vragen werden ook gesteld over het oordeel van mbo'ers en hbo'ers over de mate waarin de opleiding een goede basis vormde om te starten op de arbeidsmarkt, in relatie tot de aansluiting tussen studie en werk. Deze uitkomsten zijn niet per definitie tegenstrijdig - de aansluiting zou bijvoorbeeld vooral betrekking kunnen hebben op vakinhoudelijke kennis en vaardigheden, terwijl de voorbereiding een bredere praktische betekenis heeft in de ogen van schoolverlaters - maar het roept wel vragen op over hoe men deze resultaten dient te interpreteren.

In dit rapport willen wij deze uitkomsten aan een nadere analyse onderwerpen op basis van de gegevens die beschikbaar zijn in het SchoolverlatersInformatieSysteem (SIS) van het ROA. Doelstelling is daarbij handvatten te bieden op welke manier men met uitkomsten wat de voorbereiding op vervolgonderwijs/werk en de aansluiting met vervolgonderwijs/werk betreft om dient te gaan.

Als anker gebruiken we daarbij een tweetal vragen uit de vragenlijsten die afgenomen worden onder de gediplomeerden van het vmbo, het havo/vwo, het mbo en het hbo:

\section{$\underline{\mathrm{VMBO}}$}

1. Hoe is de aansluiting tussen de gevolgde vmbo-opleiding en je vervolgopleiding?

2. Hoe tevreden ben je over de voorbereiding op je vervolgopleiding? 


\section{HAVO/VWO}

1. Hoe is de aansluiting tussen de gevolgde havo/vwo-opleiding en je vervolgopleiding?

2. Alle aspecten overziend, hoe goed heeft de gevolgde havo/vwo-opleiding je voorbereid voor je (vervolg)opleiding?

\section{$\underline{\mathrm{MBO}}$}

1. Hoe is de aansluiting tussen de gevolgde bol/bbl-opleiding en uw huidige functie/ werkzaamheden?

2. In welke mate biedt uw bol/bbl-opleiding een goede basis om te starten op de arbeidsmarkt?

\section{$\underline{\mathrm{HBO}}$}

1. Hoe is de aansluiting tussen de gevolgde hbo-opleiding en uw huidige functie/werkzaamheden?

2. In welke mate biedt uw hbo-opleiding een goede basis om te starten op de arbeidsmarkt?

Voor het vmbo, havo en het vwo wordt daarmee de focus gelegd op voorbereiding op en aansluiting met het vervolgonderwijs, terwijl bij het mbo en het hbo wordt gekeken hoe de aansluiting is op de huidige functie en in welke mate de opleiding een goede basis vormde om te starten op de arbeidsmarkt. Daarbij analyseren we nader wat de samenhang van deze indicatoren is met objectieve onderwijs- en arbeidsmarktuitkomsten, met andere oordelen over de opleiding, met competenties en, in het geval van de arbeidsmarktintrede, in welke mate ze conjunctureel beïnvloed zijn. Deze analyses hoeven niet per se als causaal te worden opgevat. Hun functie is eerder om (verschillen in) de diepere betekenis van de betreffende indicatoren bloot te leggen, door vast te stellen met welke andere indicatoren ze wel of niet samenhangen.

Het voorliggende rapport is als volgt opgebouwd. Paragraaf 2 geeft kort inzicht in de onderliggende data. Paragraaf 3 richt zich op de doorstroom naar het vervolgonderwijs waarbij we in paragraaf 3.1 de uitkomsten onder de gediplomeerden van het vmbo nader analyseren en in paragraaf 3.2 ons richten op de gediplomeerden van het havo en het vwo. Paragraaf 4 richt zich op het intrede op de arbeidsmarkt van mbo-gediplomeerden (4.1) en de afgestudeerden van het hbo (4.2). In paragraaf 5 stellen we ons de vraag of jongens en meisjes aan de ene kant en jongeren van verschillende etnische herkomst aan de andere kant verschillend oordelen en wat hiervoor eventuele oorzaken kunnen zijn. Tot slot vat paragraaf 6 de uitkomsten samen. 


\section{2 DATA}

Het ROA voert reeds sinds het begin van de jaren negentig in vrijwel alle sectoren van het onderwijs onderzoek onder gediplomeerde schoolverlaters uit. Sinds 1996 zijn deze schoolverlatersonderzoeken in belangrijke mate op elkaar afgestemd en bestaan uit de volgende monitoren:

- VO-Monitor gericht op de uitstroom uit het voortgezet onderwijs (vmbo, havo, vwo)

- MBO-Monitor gericht op de uitstroom uit het mbo (bol en bbl)

- HBO-Monitor die wordt gehouden onder afgestudeerden van het hbo

Voor alle monitoren geldt dat er landelijke enquêtes gehouden worden onder de gediplomeerden schoolverlaters en afgestudeerden ongeveer anderhalf jaar na het behalen van het diploma. Met andere woorden, de gediplomeerden van bijvoorbeeld het schooljaar 2010-2011 zijn in 2012 benaderd.

De analyses in het voorliggende rapport zijn deels gebaseerd op subgroepen afkomstig van de 4 monitoren, waarbij in bijna alle gevallen een aantal cohorten' samengevoegd zijn om tot betrouwbarere uitspraken te komen.

- VO-Monitor

- Gediplomeerden van het vmbo van de schooljaren 2010/2011 tot en met 2012/2013 welke na behalen van het diploma zijn doorgestroomd naar een mbo-opleiding.

- Gediplomeerden van het havo/vwo van de schooljaren 2009/2010 tot en met 2012/2013 welke na behalen van het diploma zijn doorgestroomd naar een hboopleiding (uitstroom havo) of een opleiding aan een universiteit (uitstroom vwo).

- MBO-Monitor

- Gediplomeerden van het mbo (bol en bbl) van de schooljaren 2009/2010 tot en met 2012/2013 welke anderhalf jaar na behalen van het diploma tot de werkzame beroepsbevolking behoren.

- HBO-Monitor

- Afgestudeerden van een voltijd bacheloropleiding van de studiejaren 2011/2012 en 2012/2013 welke anderhalf jaar na behalen van het diploma tot de werkzame beroepsbevolking behoren.

1 Het aantal cohorten dat geanalyseerd is verschilt per monitor. Dit heeft met het aantal respondenten per meetjaar en wijzigingen in de vragenlijst te doen. 
- Afgestudeerden van kunstenopleidingen zijn daarbij buiten beschouwing gehouden aangezien zij een aparte vragenlijst kennen.

Tabel 2.1 geeft per monitor a) de meetjaren geselecteerd voor de analyses en b) het aantal respondenten per monitor weer dat aan de navolgende analyses onderliggend is.

TABEL 2.1

\begin{tabular}{|l|c|c|}
\hline Monitor & Meetjaren & Aantal respondenten \\
\hline VO-Monitor: vmbo & $2012-2014$ & 5.220 \\
\hline VO-Monitor: havo/vwo & $2011-2014$ & 3.170 \\
\hline MBO-Monitor & $2011-2014$ & 25.980 \\
\hline HBO-Monitor & $2013-2014$ & 17.100 \\
\hline
\end{tabular}

Bron: SIS (ROA), 2011 - 2014 


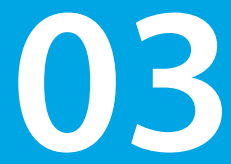

\section{AANSLUITING EN VOORBEREIDING OP VERVOLGOPLEIDING}

Aan de gediplomeerde schoolverlaters van het vmbo en het avo (havo/vwo) worden in het kader van de VO-Monitor een tweetal vragen gesteld met betrekking tot de aansluiting met en de voorbereiding op hun vervolgopleiding. De aansluiting wordt gemeten door de vraag "Hoe is de aansluiting tussen de gevolgde opleiding en de vervolgopleiding", en de voorbereiding door de vraag "Hoe tevreden ben je over de voorbereiding op je vervolgopleiding" (voor vmbo-gediplomeerden) en "Alle aspecten overziend, hoe goed heeft de gevolgde opleiding je voorbereid voor je vervolgopleiding? " (voor havo/ vwo-gediplomeerden).

In het voorliggende rapport focussen we daarbij bij de gediplomeerden van het vmbo op de groep die rechtstreeks met een mbo-opleiding is gestart. ${ }^{2}$ Wat de gediplomeerden van het havo/vwo betreft focussen we ons op de groep die de gebruikelijke route volgt, namelijk a) de overstap van de havo naar het hbo en b) de overstap van het vwo naar het wo. Tabel 1 laat zien welk percentage van de gediplomeerden van mening is dat de voorbereiding voldoende/goed was en welk percentage een voldoende/goede aansluiting vermeld.

TABEL 3.1 Oordeel van vmbo en avo gediplomeerden over voorbereiding en aansluiting op vervolgonderwijs (\%)

\begin{tabular}{l|c|c|} 
& $\begin{array}{c}\text { Voldoende/goede } \\
\text { voorbereiding } \\
\text { op vervolgonderwijs }\end{array}$ & $\begin{array}{c}\text { Voldoende/goede } \\
\text { aansluiting } \\
\text { op vervolgonderwijs }\end{array}$ \\
\hline vmbo $\rightarrow$ mbo & $49 \%$ & $78 \%$ \\
\hline havo $\rightarrow$ hbo & $76 \%$ & $74 \%$ \\
\hline vwo $\rightarrow$ wo & $85 \%$ & $85 \%$ \\
\hline
\end{tabular}

Bron:VO-Monitor (ROA): vmbo 2012-2014 / avo: 2011-2014

Tabel 3.1 laat zien dat de gediplomeerde schoolverlaters van het vmbo meestal tevreden zijn over de aansluiting tussen de gevolgde opleiding en hun mbo vervolgopleiding,

2 De VO-Monitor bevraagd ook vmbo'ers die naar de havo doorstromen. Echter, deze groep wordt in dit rapport buiten beschouwen gelaten omdat a) het zich om een relatief klein aantal respondenten handelt en b) de groep die doorstroomt naar de havo een selectieve groep is die afkomstig is van de theoretische leerweg van het vmbo. 
maar tamelijk kritisch zijn over de mate waarin hun opleiding een goede voorbereiding bood op het vervolgonderwijs. Nadere analyses laten verder zien dat bijna vier op de vijf schoolverlaters die ontevreden zijn in termen van de aansluiting dat ook zijn in termen van de voorbereiding. Van de schoolverlaters die tevreden zijn over de aansluiting blijkt echter nog geen drie op de vijf ook tevreden te zijn met de voorbereiding. Hieruit blijkt dat het hier om twee duidelijk verschillende concepten gaat voor vmbo schooverlaters. $\mathrm{Bij}$ het havo/vwo is het verschil in absolute percentages vrijwel onzichtbaar, waarbij de gediplomeerden in de regel vrij positief over zowel voorbereiding als aansluiting oordelen. Nadere analyses laten echter zien dat er meer verschil hiertussen zit dan men op basis van deze absolute percentages zou vermoeden. Bijna een derde van de schoolverlaters die negatief oordeelt over de ene indicator blijkt een positief oordeel te hebben over de andere. Alle percentages zijn tamelijk stabiel in de tijd, al blijkt vooral bij het havo/vwo enige variatie te zijn tussen de meetjaren, wat eventueel op het kleinere aantal respondenten terug te leiden is.

\section{1 vmbo naar mbo}

De centrale vraag in deze paragraaf is met welke andere indicatoren gemeten in het kader van de VO-Monitor het oordeel over de voorbereiding op en de aansluiting met het mbo correleren. Hiervoor presenteren we navolgend de uitkomsten van multivariate analyses. ${ }^{3}$ De analyses hebben betrekking op 5.220 gediplomeerden van het vmbo welke in de meetjaren 2012 tot en met 2014 de VO-Monitor vragenlijst ingevuld hebben. Deze groep jongeren heeft in de periode 2010/2011 tot en met 2012/2014 een vmbo diploma behaald en is anderhalf jaar na behalen van het diploma bevraagd. ${ }^{4}$

In eerste instantie maken we in de analyses geen direct onderscheid tussen de doorstroom naar een mbo-bol of een mbo-bbl opleiding. Nadat we de resultaten op basis van de totale groep besproken hebben, komen we echter op dit onderscheid terug. De uitkomsten van de multivariate analyses bespreken we in een tweetal stappen. Ten eerste kijken we naar de relatie tussen de voorbereiding en de aansluiting met de voorbereiding in het vmbo op specifieke competenties. Ten tweede instantie kijken we naar andere oordelen over de gevolgde vmbo-opleiding zoals de breedte van de vmboopleiding, de hoeveelheid praktijk en de kwaliteit van de docenten. Voordat we echter op deze twee centrale onderdelen ingaan, is het interessant om kort stil te staan bij een aantal uitkomsten op basis van a) de gevolgde opleiding in het vmbo en b) de gekozen opleiding in het mbo. ${ }^{5} \mathrm{Om}$ te beginnen vinden we dat tussen de gevolgde sectoren dan wel leerwegen in het vmbo zich weinig verschillen voordoen (zie ook tekstbox 1). Kijken we naar de effecten van de gekozen mbo-opleiding, dan zien we dat zich geen significante verschillen voordoen tussen de doorstroom naar het mbo-bol en de doorstroom

3 Voor de volledige resultaten van de multivariate analyses, zie Bijlage I.

4 Voor een uitgebreidere overzicht van resultaten afkomstig van de VO-Monitor, zie https://roastatistics.maastrichtuniversity.nl/ of de jaarlijkse rapportages "Schoolverlaters tussen onderwijs en arbeidsmarkt".

5 Verschillen tussen jongens en meisjes en tussen jongeren van niet-westerse herkomst en autochtonen worden in paragraaf 5 nader besproken. 
naar het mbo-bbl. Ook het niveau van de mbo-opleiding in welke men instroomt, is niet van invloed. Niet verrassend vinden we echter dat respondenten die binnen het eerste anderhalf jaar na starten in het mbo alweer met de opleiding gestopt zijn, negatiever oordelen over de voorbereiding van het vmbo op de gekozen opleiding alsmede de aansluiting tussen de gevolgde vmbo- en de gekozen mbo-opleiding dan jongeren die de opleiding nog volgen. Een goede voorbereiding en een goede aansluiting lijken dan ook belangrijke factoren voor het succesvol starten in het mbo.

Doorstroom naar vervolgonderwijs: verwante doorstroom en voorbereiding op competenties

Figuur 3.1 presenteert de gestandaardiseerde coëfficiënten afkomstig van de multivariate analyses met betrekking tot a) de verwante doorstroom en b) de competenties die in de VO-monitor gemeten worden. Wat de competentie items betreft gaat het daarbij om de vraag of het vmbo de respondenten voldoende heeft voorbereid op de gekozen vervolgopleiding. Een verwante doorstroom tussen vmbo en mbo is gedefinieerd als een doorstroom waarbij in het vmbo dezelfde sector is gevolgd als in het mbo (bijvoorbeeld van vmbo groen naar mbo groen).

Wat de verwante dan wel niet-verwante doorstroom betreft is de uitkomst duidelijk. Respondenten die een verwante doorstroom kennen oordelen significant tevredener wat de aansluiting betreft maar niet wat de voorbereiding betreft. Dit lijkt erop te duiden dat voorbereiding op de vervolgopleiding inderdaad door de respondenten anders geïnterpreteerd wordt dan aansluiting. De vraag is of we dit verder bevestigd zien als we naar de uitkomsten met betrekking tot de competentie items kijken.

Zoals verwacht, zien we dat vooral de voorbereiding op het mbo gecorreleerd is met een aantal oordelen wat de competenties voorbereiding betreft. Zo oordelen jongeren die tevreden zijn met de algemene voorbereiding positiever over de voorbereiding wat het zelfstandig werken, met de computer werken, het in de praktijk kunnen werken, de Nederlandse taalvaardigheid en de Engelse taalvaardigheden alsmede vakkennis betreft. Wat de aansluiting betreft, zien we dat dit oordeel 'slechts' met een drietal items gecorreleerd is, namelijk met de voorbereiding op zelfstandig werken, met de computer werken en de voorbereiding op vakkennis. De relatie met vakkennis is daarbij het sterkst.

Samenvattend zien we dat voorbereiding en aansluiting door de jongeren zeker niet als twee identieke concepten gezien worden. Een goede voorbereiding vereist een breder competentiepakket dan een goede aansluiting. 
FIGUUR 3.1 Voorbereiding en aansluiting: verwante doorstroom en relatie met competenties

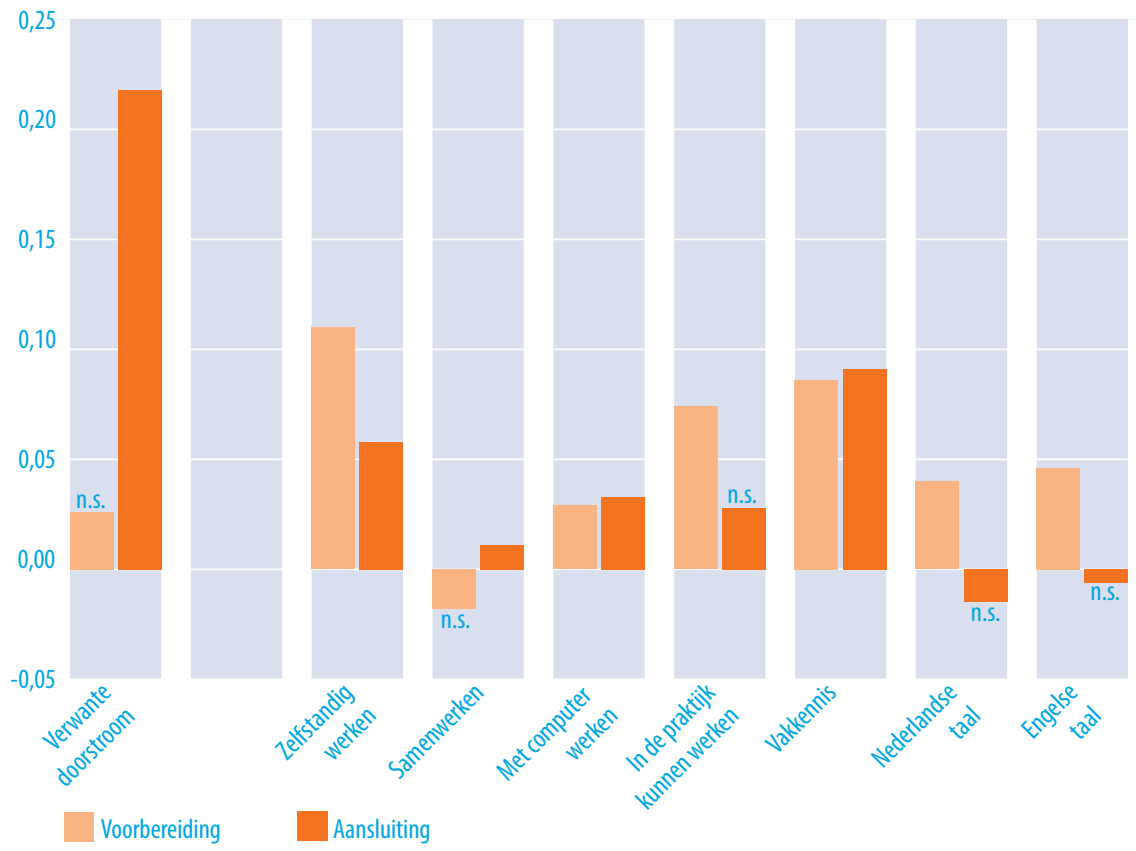

Bron: VO-Monitor (ROA): vmbo 2012-2014

Noot: n.s. $=$ niet significant

\section{Doorstroom naar vervolgonderwijs: relatie met andere oordelen over het vmbo}

Naast de vraag in hoeverre voorbereiding en aansluiting samenhangen met verwante doorstroom en voorbereiding op bepaalde competenties, is het op basis van de VO-Monitor ook mogelijk om de correlatie met een aantal andere oordelen over de vmbo-opleiding vast te stellen. Figuur 3.2 presenteert, afkomstig van dezelfde multivariate analyse, de gestandaardiseerde coëfficiënten van deze verdergaande oordelen over de gevolgde vmbo-opleiding op voorbereiding en aansluiting.

Voordat we op eventuele verschillen tussen 'voorbereiding' en 'aansluiting' te spreken komen, kan opgemerkt worden dat respondenten die positief oordelen over de voorbereiding dan wel de aansluiting in de regel ook positief over andere aspecten van de vmbo-opleiding oordelen. Daarbij lijkt de relatie wederom sterker en breder wat het oordeel over de voorbereiding dan wat het oordeel over de aansluiting betreft. Zo kent slechts de 'tevredenheid met de hoeveelheid praktijk' en 'vmbo-opleiding was te breed' geen significante relatie met de voorbereiding. Naast deze twee indicatoren kent wat de relatie met de aansluiting betreft ook de 'kwaliteit van docenten' geen invloed. Wat de hoogte van de invloeden betreft, zien we dat de voorbereiding een relatief sterke relatie kent met 'de basis die de vmbo-opleiding bood om competenties verder te ontwik- 
kelen'. Dit is in lijn met onze eerdere bevinding dat het oordeel over de voorbereiding op de vervolgopleiding relatief sterk samenhangt met een brede range van (generieke) competenties. Daarnaast zien we dat een goede voorbereiding ook een relatie kent met een hoge kwaliteit van de docenten en een goede voorlichting over de mogelijke vervolgstappen. Niet verrassend is het laatste aspect ook sterk gecorreleerd met een goede aansluiting. Immers, we kunnen verwachten dat een goede voorlichting ervoor zorgt dat vmbo-gediplomeerden in een mbo-opleiding terecht komen die goed bij hun competenties en verwachtingen past.

\section{FIGUUR 3.2 Voorbereiding en aansluiting: relatie met andere oordelen}

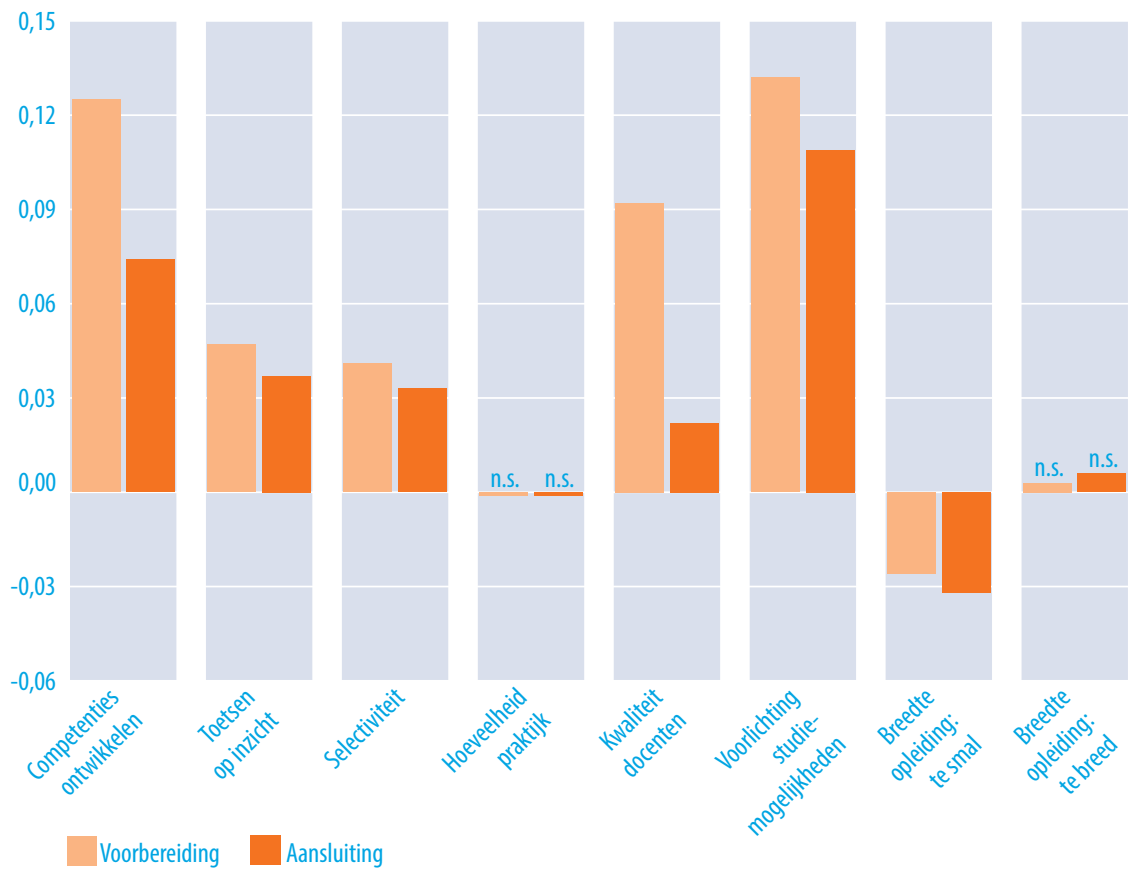

Bron: VO-Monitor (ROA): vmbo 2012-2014

Noot: n.s. $=$ niet significant

Samenvattend kan tot nu toe vastgesteld worden dat:

- de aansluiting door respondenten meer geïnterpreteerd wordt als de beoordeling van de vakinhoudelijke overgang en

- de voorbereiding meer naar een breed pallet aan vaardigheden en kennis refereert. 
Tabel B1.1 laat zien dat $46 \%$ van de gediplomeerde vmbo-ers zowel wat de aansluiting als wat de voorbereiding op de vervolgopleiding betreft tevreden is. Nog eens $32 \%$ is weliswaar tevreden met de aansluiting maar niet met de voorbereiding. Bijna een op de vijf is uiteindelijk zowel wat de voorbereiding betreft als wat de aansluiting betreft ontevreden. Wat de verschillende subgroepen betreft, komen opvallend weinig verschillen naar voren.

TABEL B1.1 Tevredenheid per subgroepen (\%)

\begin{tabular}{|l|c|c|c|c|c|}
\hline & $\begin{array}{l}\text { Voorbereiding: } \\
\text { Ontevreden } \\
\text { Aansluiting: } \\
\text { Ontevreden }\end{array}$ & $\begin{array}{l}\text { Voorbereiding: } \\
\text { Tevreden } \\
\text { Aansluiting: } \\
\text { Ontevreden }\end{array}$ & $\begin{array}{l}\text { Voorbereiding: } \\
\text { Ontevreden } \\
\text { Aansluiting: } \\
\text { Tevreden }\end{array}$ & $\begin{array}{l}\text { Voorbereiding: } \\
\text { Tevreden } \\
\text { Aansluiting: } \\
\text { Tevreden }\end{array}$ & \\
\hline VMB0 & 18 & 5 & 32 & 46 & $100 \%$ \\
\hline VMB0-TL & 17 & 5 & 34 & 44 & $100 \%$ \\
\hline VMB0-GL & 14 & 6 & 30 & 51 & \\
\hline VMB0-KB & 19 & 5 & 30 & 46 & $100 \%$ \\
\hline VMB0-BB & 16 & 4 & 32 & 47 & $100 \%$ \\
\hline $\begin{array}{l}\text { Doorstroom naar } \\
\text { mbo-bol }\end{array}$ & 17 & 5 & 32 & 46 & $100 \%$ \\
\hline $\begin{array}{l}\text { Doorstroom naar } \\
\text { mbo-bbl }\end{array}$ & 19 & 5 & 31 & 46 & $100 \%$ \\
\hline $\begin{array}{l}\text { Doorstroom naar mbo } \\
\text { niveau 1/2 }\end{array}$ & 18 & 6 & 31 & 45 & $100 \%$ \\
\hline $\begin{array}{l}\text { Doorstroom naar mbo } \\
\text { niveau 3/4 }\end{array}$ & 17 & 5 & 33 & 46 & $100 \%$ \\
\hline
\end{tabular}

Bron: V0-Monitor 2011-2014

In aanvulling aan de analyses die in het rapport besproken zijn en de beschrijvende resultaten zoals in Tabel B1.1 gepresenteerd, zijn multinomiale analyses uitgevoerd op de vier combinaties (zie Tabel B1.1.) wat de tevredenheid met voorbereiding en aansluiting betreft (basis = tevreden met voorbereiding en tevreden met aansluiting). Voor een overzicht van de meegenomen controlevariabelen, zie Bijlage V. Deze bevestigen de resultaten zoals in het rapport besproken met als centrale uitkomsten (zie ook Figuur B1.1).

- Gegeven dat men tevreden is met de voorbereiding op de vervolgopleiding:

0 het verschil tussen tevreden zijn met de aansluiting en ontevreden zijn met de aansluiting met de vervolgopleiding wordt sterk bepaalt door de vraag of men binnen een bepaald sector doorgestroomd is ('verwante doorstroom');

- Gegeven dat men tevreden is met de aansluiting tussen opleiding en vervolgopleiding:

0 het verschil tussen tevreden zijn met de voorbereiding en ontevreden zijn met de voorbereiding op de vervolgopleiding wordt, bepaald door vakkennis en een breder set aan generieke competenties opgedaan in de opleiding. 
TEKSTBOX 1 VMBO: Samenhang tussen voorbereiding en aansluiting: Nadere analyses

FIGUUR B1.1 Relatie tussen tevredenheid en 'verwante doorstroom' /'competenties' (log-odds ratios)

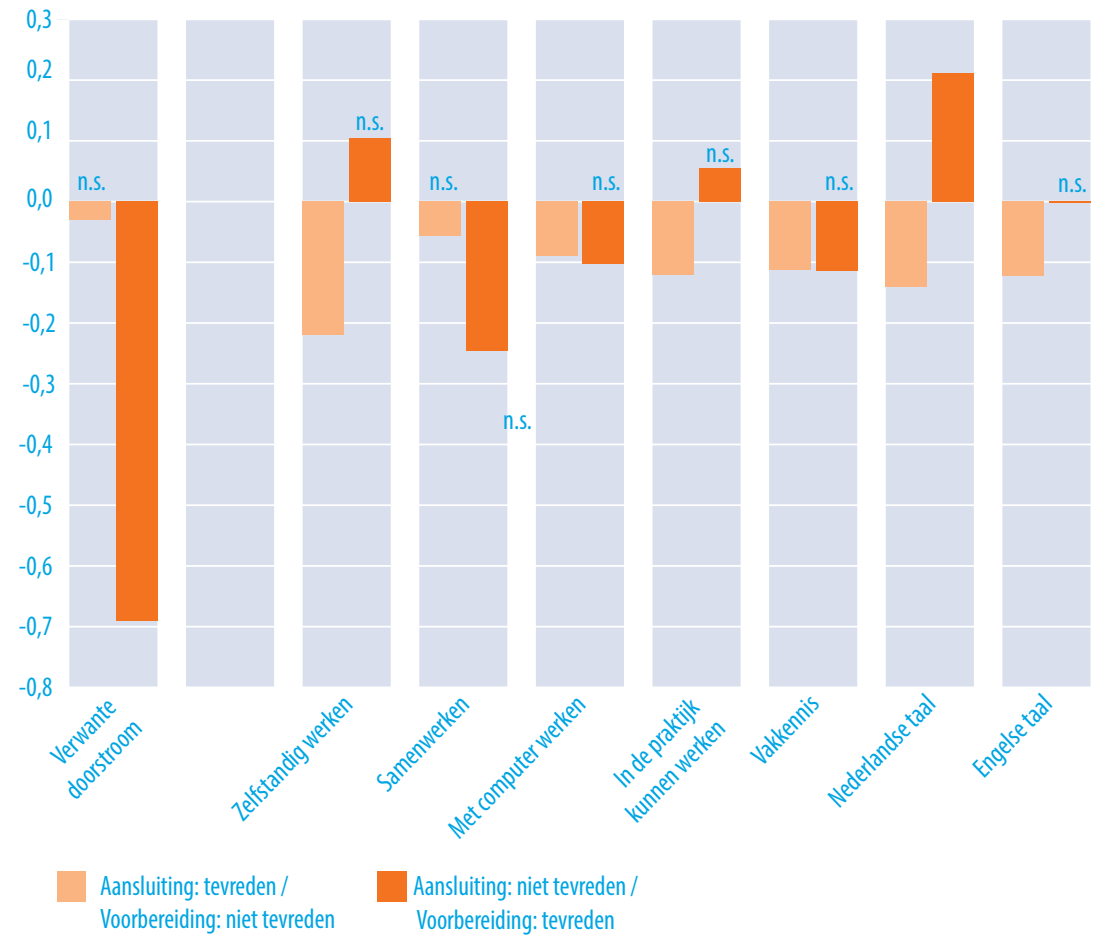

Bron: V0-Monitor 2011-2014

Noot: n.s. = niet significant

Tot slot van deze paragraaf staan we kort stil bij de vraag of de overgang naar een mbo-bol opleiding wat deze aspecten betreft verschilt van de overgang naar een mbo-bbl opleiding. Hiervoor zijn de boven besproken multivariate analyses afzonderlijk voor de twee groepen (vmbo $\rightarrow$ mbo-bol en vmbo $\rightarrow$ mbo-bbl) uitgevoerd. Deze afzonderlijke analyses laten zien dat

- de boven gepresenteerde uitkomsten relatief robuust zijn, dat wil zeggen dat zich geen grote verschillen voordoen tussen degenen die voor een mbo-bol opleiding en degenen die voor een mbo-bbl opleiding hebben gekozen.

- In beide gevallen de aansluiting hoofdzakelijk door de verwantheid van de gevolgde vmbo-opleiding en de gekozen mbo-opleiding en een goede voorbereiding op de gevraagde vakkennis wordt beïnvloedt. 
- Dat de voorbereiding op een mbo-bol opleiding in de regel sterker door een goede voorbereiding op generieke competenties zoals de Nederlandse taal of de Engelse taal beïnvloedt wordt dan de voorbereiding op een mbo-bbl opleiding. ${ }^{6}$

\section{2 havo/vwo naar hbo/wo}

In tegenstelling tot de uitkomsten onder de vmbo-gediplomeerden, liet Tabel 1 zien dat de oordelen over de voorbereiding en de aansluiting zich onder de gediplomeerden van het havo/vwo niet duidelijk van elkaar lieten onderscheiden. De vraag is of dit ook terug te zien is in de correlaties tussen de antwoorden op de twee oordeelsvragen en andere indicatoren die gemeten worden in de VO-Monitor onder de havo/vwo-gediplomeerden. Hiervoor analyseren we wederom via multivariate analyses de voorbereiding op en aansluiting met het vervolgonderwijs.? We focussen daarbij op jongeren die na hun diploma de gebruikelijke route gevolgd zijn, en vanuit het vwo naar het wo of vanuit het havo naar het hbo doorgestroomd zijn. De analyses hebben betrekking op zo'n 3.200 gediplomeerden van het havo/vwo welke in de meetjaren 2011 tot en met 2014 de VO-Monitor vragenlijst ingevuld hebben. Bijna 1.400 van hen zijn afkomstig van het havo en zijn rechtstreeks naar het behalen van het diploma gestart met een hbo-opleiding. De andere 1.800 zijn afkomstig van het vwo en zijn na behalen van het diploma met een opleiding aan een universiteit gestart. ${ }^{8}$

In eerste instantie presenteren we de resultaten op basis van de totale groep respondenten. Aan het einde van deze paragraaf staan we echter ook kort stil bij eventuele verschillen tussen de overstap van het havo naar het hbo en de overstap van het vwo naar het wo. De bespreking van de uitkomsten van de multivariate analyses doen we wederom in een tweetal stappen: a) de effecten van competenties en b) de relatie met andere oordelen.

\section{Doorstroom naar vervolgonderwijs: Verwante doorstroom en voorbereiding op competenties}

Figuur 3.3 presenteert de gestandaardiseerde coëfficiënten afkomstig van de multivariate analyse met betrekking tot de competenties die in de VO-monitor gemeten worden. Hierbij gaat het bij de individuele items om de vraag wat het eigen niveau (zelf inschatting) van de respondenten op moment van enquête is. Dit in tegenstelling tot paragraaf 3.1 waar we de voorbereiding op dit item discuteerden. We dienen bij de interpretatie van de resultaten er dan ook rekening mee te houden dat het niveau qua

6 Daarbij dienen we rekening mee te houden dat a) het beschikbare aantal cases dat doorgestroomd is naar een mbo-bbl opleiding aanzienlijk kleiner is dan het aantal beschikbare cases dat doorgestroomd is naar een mbo-bol opleiding en b) dat zich een selectiviteitsprobleem kan voordoen. Immers, jongeren die een mbo-bbl opleiding volgen zijn door een werkgever geselecteerd wat de heterogeniteit binnen deze groep in vergelijking met de heterogeniteit binnen de groep die het mbo-bol ingestroomd is kan beïnvloeden. Voor de volledige resultaten van de multivariate analyses, zie Bijlage II.

8 Voor een uitgebreidere overzicht van resultaten afkomstig van de VO-Monitor, zie https://roastatistics.maastrichtuniversity.nl/ of de jaarlijkse rapportages "Schoolverlaters tussen onderwijs en arbeidsmarkt". 
competenties op moment van enquête (en daarmee tijdens het volgen van de hbo of wo-opleiding) gemeten is en niet per definitie overeen dient te komen met het niveau dat men aan het einde van de havo- of vwo-opleiding bezat. Ondanks deze kanttekening is een analyse van competenties interessant voor het voorliggende rapport aangezien we vooral geïnteresseerd in zijn of er verschillen in de relatie tussen competenties en het oordeel over de voorbereiding dan wel tussen competenties en het oordeel over de aansluiting te vinden zijn.

FIGUUR 3.3 Voorbereiding en aansluiting: relatie met competenties

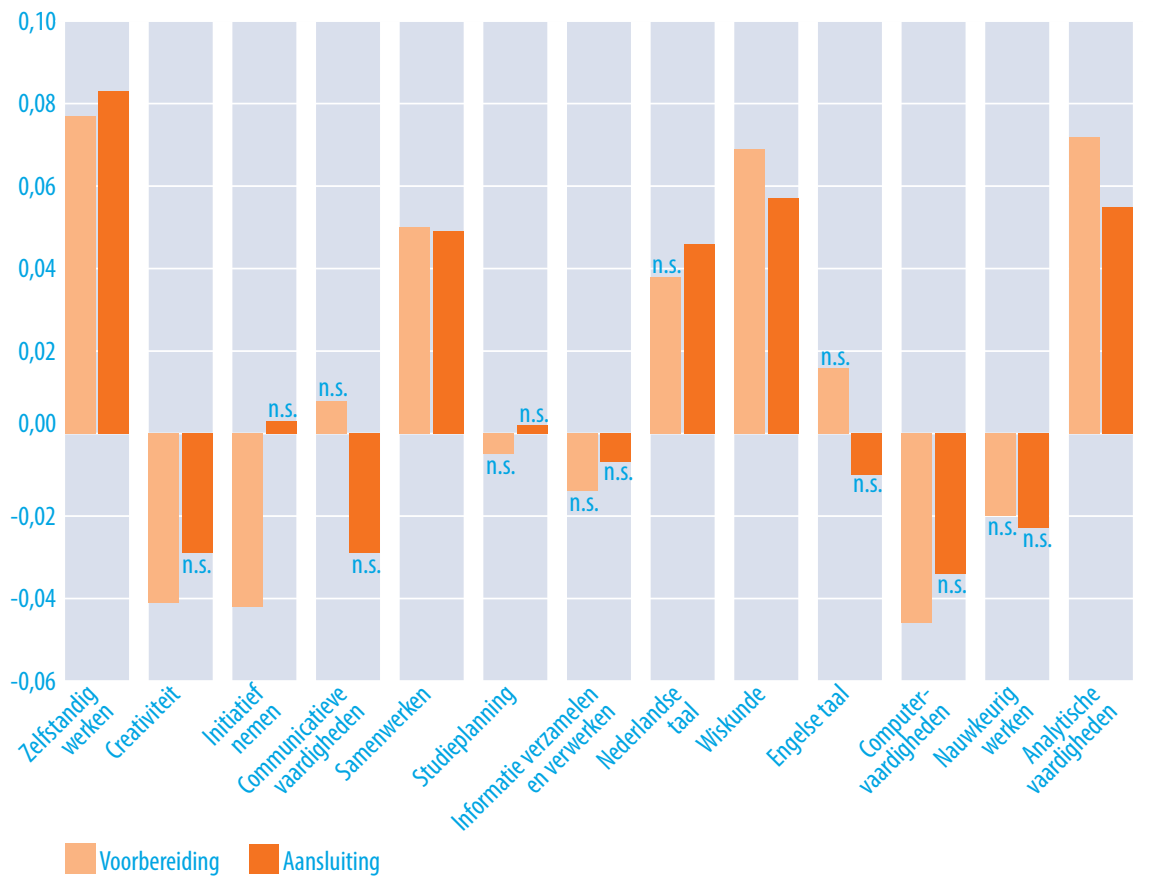

Bron: VO-Monitor (ROA): avo: 2011-2014

Noot: n.s. $=$ niet significant

Wat direct opvalt, en in tegenstelling tot de analyse onder de vmbo-gediplomeerden, is dat bij 10 van de 13 onderscheiden items de effecten afkomstig van de twee analyses sterk vergelijkbaar zijn. Een hoger niveau van 'zelfstandig werken', 'samenwerken,' 'wiskunde' en 'analytische vaardigheden' gaat gepaard met zowel een hogere tevredenheid wat de voorbereiding als wat de aansluiting betreft. Wat het effect van 'Nederlandse taal' 
(positieve correlatie) en 'creativiteit' (negatieve correlatie') betreft is weliswaar een van de twee effecten niet significant verschillend van nul, maar het verschil tussen de twee analyses is nihil. Ook bij de niet-significante effecten zien we in de regel geen duidelijke verschillen in de effecten.

Het onderzoek onder de havisten en vwo'ers geeft ons daarnaast, in tegenstelling tot het onderzoek onder de vmbo-gediplomeerden, ook de mogelijkheid om een eventueel tekort of een eventueel overschot in competenties vast te stellen. Naast een eigen inschatting van het niveau aan competenties is namelijk per item ook gevraagd wat het vereiste niveau in de vervolgopleiding is. De analyses laten zien dat in de regel een tekort, maar vaak ook een overschot, een negatieve correlatie met het oordeel over de voorbereiding en de aansluiting kent. Ook hier zijn geen grote verschillen tussen 'voorbereiding' en 'aansluiting' te vinden en lijkt het erop dat de respondenten geen duidelijk onderscheid tussen deze twee concepten en hun relatie met competenties tekorten of overschotten maken. De relatief sterkste effecten vinden we bij een tekort aan 'zelfstandig kunnen werken', een tekort aan 'initiatief nemen', een tekort aan 'studieplanning' en een tekort aan 'informatie verzamelen en verwerken'. Bij al deze generieke competenties geldt dat een tekort zowel het oordeel wat de voorbereiding betreft als het oordeel wat de aansluiting betreft negatief beïnvloedt. Daarbij zien we dat 'studieplanning' en 'initiatief nemen' een sterkere effect op voorbereiding dan op de aansluiting kennen.

Tot slot is wat de competenties betreft wederom een indicator opgenomen die een indicatie geeft of de vervolgopleiding als verwant aan de gevolgde opleiding gezien kan worden of niet. In tegenstelling tot de doorstroom van het vmbo naar het mbo is bij de doorstroom van het havo/vwo naar het hoger onderwijs deze verwantschap echter minder eenduidig. In het kader van de voorliggende analyses is daarom ervoor gekozen om de verwantschap te definiëren als de meest voorkomende doorstroom tussen het gevolgde profiel in het voortgezet onderwijs en de studierichting in het hoger onderwijs. Als verwante doorstroom zijn daarbij de volgende routes gedefinieerd (profiel in havo/vwo $\rightarrow$ studierichting in hbo/wo):

- Cultuur en maatschappij $\rightarrow$ Gedrag en maatschappij

- Economie en maatschappij $\rightarrow$ Economie

- Natuur en gezondheid $\rightarrow$ Gezondheidszorg

- Natuur en techniek $\rightarrow$ Techniek

- Combinatieprofiel $\rightarrow$ Techniek / Gezondheidszorg

In tegenstelling tot de analyses onder de vmbo-gediplomeerden laten de uitkomsten van de voorliggende twee multivariate analyses in dit geval echter geen significante

9 Nadere analyses laten zien dat de negatieve correlatie tussen het'eigen niveau aan creativiteit'en het oordeel wat de 'voorbereiding' betreft relatief sterk beïnvloedt wordt door de gediplomeerden die in de hbo sector 'kunst, taal en cultuur' instromen. Deze groep meldt aan de ene kant namelijk het hoogste eigen niveau aan creativiteit en tegelijkertijd oordeelt deze groep relatief kritisch wat de voorbereiding betreft. 
invloed van de verwantschap van de doorstroom op de aansluiting of de vraag hoe men voorbereid is zien.

\section{Doorstroom naar vervolgonderwijs: relatie met andere oordelen over het havo/vwo}

Naast de vraag in hoeverre voorbereiding en aansluiting samenhangen met verwante doorstroom en bepaalde competenties, is het ook bij de gediplomeerden van het havo en het vwo mogelijk om de correlatie met een aantal andere oordelen over de havo-/ vwo-opleiding vast te stellen. Figuur 3.4 presenteert, afkomstig van dezelfde multivariate analyse, de gestandaardiseerde coëfficiënten.

In lijn met onze bevindingen wat de competenties betreft, zien we ook met betrekking tot andere oordelen dat de respondenten in de regel geen verschil in de relatie tussen 'voorbereiding' en 'andere oordelen' aan de ene kant en 'aansluiting' en 'andere oordelen' aan de andere kant maken. Weliswaar zijn de effecten, zeker wat de indicator 'kwaliteit van de docenten' betreft sterker met betrekking tot de voorbereiding dan met betrekking tot de aansluiting, maar de verschillen zijn relatief klein.

FIGUUR 3.4 Voorbereiding en aansluiting: relatie met andere oordelen
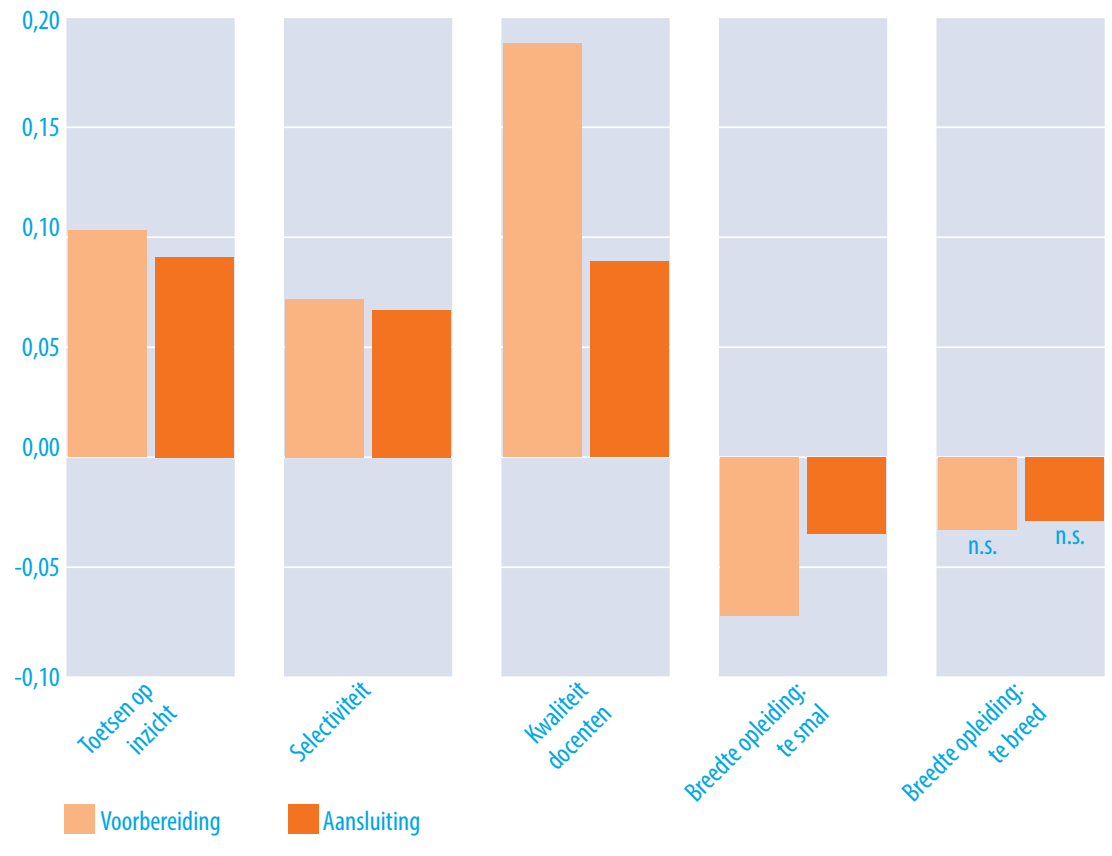

Bron: VO-Monitor (ROA): avo: 2011-2014

Noot: n.s. = niet significant 
Samenvattend kunnen we dan ook stellen dat:

- respondenten van het havo/vwo de twee indicatoren 'voorbereiding op vervolgopleiding' en 'aansluiting met vervolgopleiding' duidelijk minder als twee aparte concepten zien dan de vmbo-gediplomeerden.

- Een mogelijke verklaring, welke echter nader onderzoek vereist, is dat dat de doorstroom van het vmbo naar het mbo in de beroepskolom plaatsvindt terwijl het zich bij de doorstroom van het havo/vwo naar het hoger onderwijs sterker om een overgang van een algemene opleiding naar een algemene vervolgopleiding handelt. Ondanks dat het hoger onderwijs eveneens specifieke studierichtingen kent die gepaard gaan met het aanleren van vakspecifieke competenties dient het hoger onderwijs in de regel wel als minder beroepsgericht getypeerd te worden dan het middelbaar beroepsonderwijs. Of dit echter ook geldt als we ons richten op de doorstroom vanuit het havo naar het hbo, het relatief sterk beroepsgerichte deel van het hoger onderwijs, is de vraag die we ons tot slot van dit paragraaf stellen.

TEKSTBOX 2 HAVO-VWO: Samenhang tussen voorbereiding en aansluiting: Nadere analyses

In aanvulling aan de analyses die in het rapport besproken worden, zijn multinomiale analyses uitgevoerd op vier combinaties wat de tevredenheid met voorbereiding en aansluiting betreft (voorbereiding: tevreden/ontevreden, aansluiting: tevreden/ontevreden). Voor een overzicht van de meegenomen controlevariabelen, zie Bijlage V. Deze bevestigen de resultaten zoals in het rapport besproken met als centrale uitkomsten:

- dat de gediplomeerden van het havo/vwo de twee indicatoren 'voorbereiding op vervolgopleiding' en 'aansluiting met vervolgopleiding' duidelijk minder dan de gediplomeerden van de andere onderscheiden onderwijsgroepen als twee aparte concepten zien. Ten gevolge hiervan zijn niet duidelijke indicatoren vast te stellen die het verschil tussen 'tevreden op allebeide indicatoren' en 'tevreden met aansluiting maar niet met voorbereiding' (of 'tevreden met voorbereiding maar niet met aansluiting') bepalen.

- Respondenten die met allebei aspecten ontevreden zijn (in vergelijking met respondenten die met allebei aspecten tevreden zijn) oordelen in de regel ook kritischer over andere aspecten van de gevolgde opleiding, kennen vaak een lager niveau aan competenties en tot slot een grotere kans op een mismatch tussen de competenties die in de vervolgopleiding vereist zijn en het eigen niveau aan competenties.

\section{Doorstroom naar vervolgonderwijs: verschil tussen havo $\rightarrow$ hbo en vwo $\rightarrow$ wo}

De uitkomsten van een tweetal sets van analyses afzonderlijk voor de groep gediplomeerden van het havo die doorstromen naar het hbo en de groep gediplomeerden van het vwo die doorstromen naar het wo laten zien dat de algemene uitkomsten in de regel ook voor de twee afzonderlijke groepen gelden. Weliswaar verliezen de individuele indicatoren aan significantie wat met het relatief kleine aantal respondenten per subgroep 
te doen kan hebben, maar het algemene beeld blijft sterk overeen. De enige duidelijke verschillen die zichtbaar worden, zijn:

- De correlatie tussen a) voorbereiding of b) aansluiting met andere oordelen over de gevolgde opleiding zijn in de regel sterker onder de groep vwo'ers die naar het wo zijn doorgestroomd dan onder de groep havisten die naar het hbo doorgestroomd zijn;

- Een verwante doorstroom is wat de voorbereiding betreft belangrijker voor havisten die naar het hbo doorstromen dan voor vwo'ers die naar het wo doorstromen. Dit kan samenhangen met het feit dat hbo-opleiding in de regel smaller van opzet zijn dan wo-opleidingen en daarmee een match tussen het profiel in het voortgezet onderwijs en de studierichting in het hoger onderwijs belangrijker wordt;

- Een achteraf'te smalle' vooropleiding heeft een sterker negatieve effect op de voorbereiding van vwo'ers op een wo-opleiding dan voor de voorbereiding van havisten op het hbo. Dit kan wederom ermee samenhangen dat hbo-opleidingen smaller van opzet zijn dan wo-opleidingen. 



\section{4 \\ AANSLUITING EN VOORBEREIDING OP HUIDIGE FUNCTIE}

Nadat in paragraaf 3 de voorbereiding op en aansluiting met het vervolgonderwijs centraal stonden, richten we ons in deze paragraaf op de voorbereiding op en de aansluiting met het werk dat jongeren na het verlaten van het onderwijs vinden. We doen dit achtereenvolgend voor de gediplomeerden van het $\mathrm{mbo}^{10}$ en de afgestudeerde bachelors ${ }^{11}$ van het hbo. In het kader van de $\mathrm{MBO}$ - en de HBO-monitor is aan de recent gediplomeerden een tweetal vragen met betrekking tot de aansluiting en voorbereiding op de arbeidsmarkt gesteld die voor de voorliggende rapportage van interesse zijn "Hoe is de aansluiting tussen de gevolgde opleiding en uw huidige functie?" en "In welke mate biedt uw gevolgde opleiding een goede basis om te starten op de arbeidsmarkt?" Aangezien de eerste vraag ('aansluiting') slechts aan de werkenden gesteld kan worden, beperken we de navolgende discussie op de gediplomeerden en afgestudeerden die anderhalf jaar na behalen van het diploma werkzaam zijn. Hierbij ligt de huidige CBS definitie met betrekking tot werkzame beroepsbevolking ten grondslag en worden jongeren die minimaal 1 uur per week werkzaam zijn en die zich tegelijkertijd niet als 'student' typeren meegenomen. ${ }^{2}$

Figuur 4.1 laat voor het mbo en het hbo de ontwikkeling in de tijd zien wat de twee indicatoren betreft. Een drietal uitkomsten zijn interessant om op te merken: Ten eerste komt de tevredenheid (voorbereiding en aansluiting) van mbo-gediplomeerden en van hbo afgestudeerden sterk overeen. Ten tweede zijn de werkenden kritischer wat de voorbereiding betreft dan wat de aansluiting betreft. Ten derde is de indicator 'voorbereiding' duidelijk meer gevoelig voor de conjunctuur dan de indicator 'aansluiting'. De daling in tevredenheid sinds 2009 dient dan ook vooral in de context van de recente economische crisis gezien te worden. ${ }^{13}$

10 Het mbo bereidt inderdaad niet alleen voor op de arbeidsmarkt maar ook op vervolgopleidingen zowel in het mbo zelf als in het hbo.

11 Voor de navolgende analyses zijn alleen de groep gediplomeerden van het hbo geselecteerd die een voltijd bacheloropleiding hebben afgerond. Daarnaast worden ook de afgestudeerden van kunstopleidingen buiten beschouwing gelaten aangezien zij een aparte vragenlijst kennen waarin een aantal kernindicatoren voor het voorliggende onderzoek niet gevraagd worden.

12 Voor een uitgebreidere discussie wat de gevolgen van de invoering van de nieuwe definitie betreft, zie ROA, $2014 b$.

13 Zie hiervoor ook ROA, 2014b. 


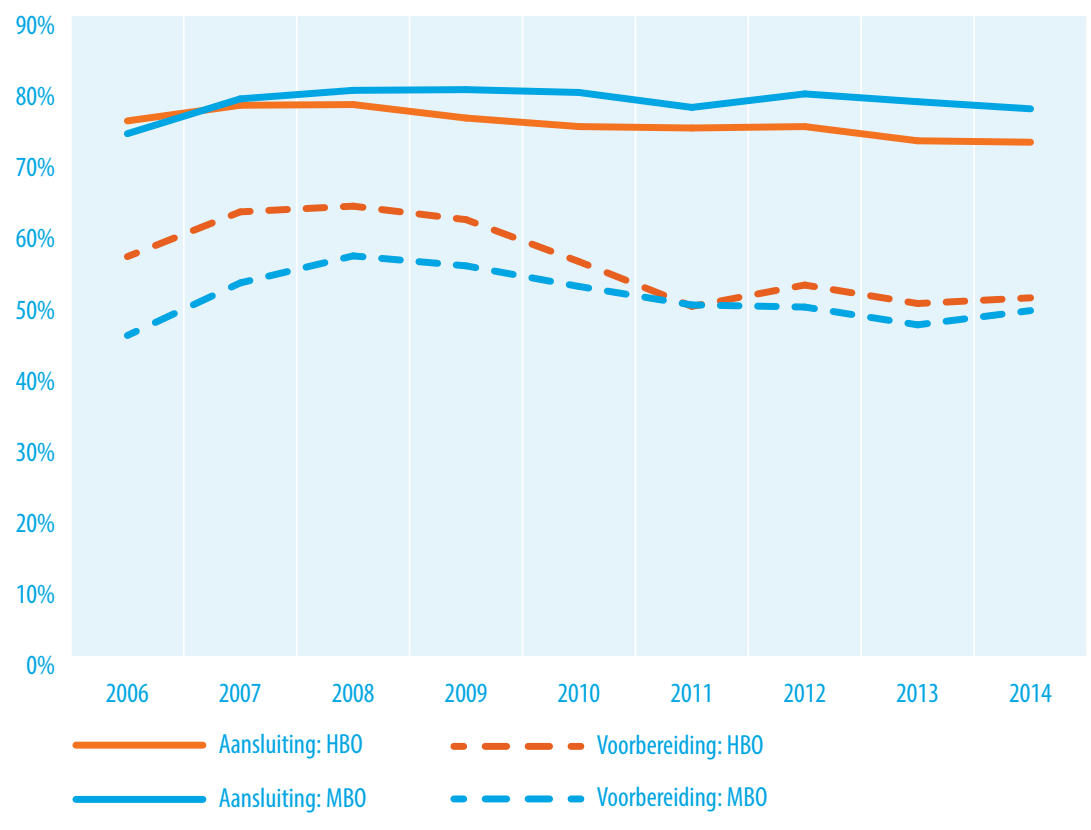

Bron: MBO-Monitor en HBO-Monitor (ROA): 2006-2014

Nadere analyses laten verder zien dat ruim driekwart van de mbo-gediplomeerden en hbo afgestudeerden die ontevreden zijn in termen van de aansluiting dat ook zijn in termen van de voorbereiding. Dat betekent wel dat bijna een kwart van deze mensen tevreden zijn over de voorbereiding ondanks het feit dat ze ontevreden zijn over de aansluiting. Van de schoolverlaters die tevreden zijn over de aansluiting is de scheiding nog minder scherp: tussen de $40 \%$ en $45 \%$ van de mbo-gediplomeerden en hbo afgestudeerden die tevreden zijn met de aansluiting is ontevreden met de voorbereiding. Dit onderstreept nogmaals het feit dat het om duidelijk gescheiden concepten gaat.

\section{1 mbo naar arbeidsmarkt}

Zo'n 70\% van de gediplomeerden van een mbo-opleiding biedt zich aan op de arbeidsmarkt. Deze groep vormt een belangrijk onderdeel van de Nederlandse beroepsbevolking en de voorbereiding op een succesvolle arbeidsmarktintrede is dan ook een cruciaal onderdeel van het mbo. Figuur 4.1 heeft al laten zien dat de werkende gediplomeerden van het mbo kritischer zijn wat de indicator 'voorbereiding' betreft dan wat de indicator 'aansluiting' betreft. Daarnaast was zichtbaar dat het oordeel over de 'voorbereiding' nogal gevoelig is voor conjuncturele verandering terwijl dit in duidelijk mindere mate het geval is bij de indicator 'aansluiting'. In deze paragraaf analyseren we de relatie van deze twee indicatoren met andere zowel objectieve als subjectieve indi- 
catoren gemeten in de MBO-Monitor op een vergelijkbare wijze als we dit deden voor de doorstroom naar het vervolgonderwijs. De volledige resultaten van de multivariate analyses zijn in Bijlage III opgenomen.

Voordat we navolgend in meer detail ingaan op de a) de rol van de horizontale en verticale match, b) de rol van competenties en c) de relatie met andere oordelen over de gevolgde mbo-opleiding is het belangrijk om te vermelden dat de multivariate analyses $^{14}$ laten zien dat de werkende gediplomeerden van het mbo-bol zowel qua 'voorbereiding' als wat de indicator 'aansluiting' betreft significant minder tevreden zijn dan de werkende gediplomeerden afkomstig van het mbo-bbl. ${ }^{15}$ Ook stijgt de tevredenheid met de voorbereiding met het toenemend niveau van het mbo diploma dat men heeft behaald, maar de tevredenheid met de aansluiting neemt af. Met andere woorden, een mbo diploma op niveau $3 / 4$ biedt weliswaar een betere voorbereiding op de arbeidsmarkt dan een mbo diploma op niveau $1 / 2$, maar leidt niet per definitie tot een betere aansluiting tussen werk en opleiding. Als laatste kan nog opgemerkt worden dat mbo-gediplomeerden die werkzaam zijn in het bedrijf waar ze tijdens de opleiding al in het kader van een BPV dan wel stageplek werkzaam waren, zowel beter oordelen over de voorbereiding als over de aansluiting.

TEKSTBOX 3 MBO: Samenhang tussen voorbereiding en aansluiting: Nadere analyses

Tabel B3.1 laat zien dat $43 \%$ van de werkzame gediplomeerde van het $\mathrm{MBO}$ zowel wat de aansluiting als wat de voorbereiding betreft tevreden is. Nog eens $35 \%$ is weliswaar tevreden met de aansluiting maar niet met de voorbereiding. Bijna een op de vijf is uiteindelijk zowel wat de voorbereiding betreft als wat de aansluiting betreft ontevreden. Wat de verschillende subgroepen betreft, komen opvallen weinig verschillen naar voren. Slechts op twee punten zijn duidelijke verschillen zichtbaar:

- de gediplomeerden van het mbo-bbl zijn duidelijk vaker tevreden wat zowel de aansluiting als voorbereiding betreft dan de gediplomeerden van het mbo-bol;

- de gediplomeerden van de sector Gezondheidszorg zijn vaker zowel tevreden wat aansluiting als voorbereiding betreft.

Deze kernresultaten blijven ook staan als er in nadere analyses rekening mee gehouden wordt dat het aandeel jongeren dat binnen het mbo een mbo-bbl opleiding volgt kan verschillen tussen a) de onderscheiden onderwijsniveaus en b) de onderscheiden onderwijssectoren.

14 Zie Bijlage III voor de volledige resultaten.

15 Op de vraag of zich in de relatie tussen 'voorbereiding'/'aansluiting' en de andere objectieve en subjectieve indicatoren afkomstig van de BVE-Monitor verschillen voordoen gaan we aan het einde van dit paragraaf nader in. 
TEKSTBOX 3 MBO: Samenhang tussen voorbereiding en aansluiting: Nadere analyses

TABEL B3.1 Tevredenheid per subgroepen (\%)

\begin{tabular}{|l|c|c|c|c|c|}
\hline & $\begin{array}{l}\text { Voorbereiding: } \\
\text { Ontevreden } \\
\text { Aansluiting: } \\
\text { Ontevreden }\end{array}$ & $\begin{array}{l}\text { Voorbereiding: } \\
\text { Tevreden } \\
\text { Aansluiting: } \\
\text { Ontevreden }\end{array}$ & $\begin{array}{l}\text { Voorbereiding: } \\
\text { Ontevreden } \\
\text { Aansluiting: } \\
\text { Tevreden }\end{array}$ & $\begin{array}{l}\text { Voorbereiding: } \\
\text { Tevreden } \\
\text { Aansluiting: } \\
\text { Tevreden }\end{array}$ & \\
\hline MB0 Totaal & 17 & 6 & 35 & 43 & $100 \%$ \\
\hline MBO-BOL & 22 & 6 & 34 & 38 & $100 \%$ \\
\hline MB0-BBL & 12 & 5 & 35 & 74 & $100 \%$ \\
\hline Niveau 1/2 & 17 & 6 & 39 & 39 & $100 \%$ \\
\hline Niveau 3/4 & 17 & 6 & 33 & 45 & $100 \%$ \\
\hline Groen & 20 & 5 & 38 & 37 & $100 \%$ \\
\hline Techniek & 16 & 6 & 35 & 43 & $100 \%$ \\
\hline Economie & 21 & 6 & 37 & 37 & $100 \%$ \\
\hline Gezondheidszorg & 10 & 5 & 30 & 55 & $100 \%$ \\
\hline Gedrag \& Maatschappij & 21 & 5 & 36 & 38 & $100 \%$ \\
\hline
\end{tabular}

Bron: MBO-Monitor 2011-2014

In aanvulling aan de analyses die in het rapport besproken zijn en de beschrijvende resultaten zoals in Tabel B3.1 gepresenteerd, zijn multinomiale analyses uitgevoerd op de vier combinaties (zie Tabel B3.1.) wat de tevredenheid met voorbereiding en aansluiting betreft (basis = tevreden met voorbereiding en tevreden met aansluiting). Voor een overzicht van de meegenomen controlevariabelen, zie Bijlage V. Deze bevestigen de resultaten zoals in het rapport besproken met als centrale uitkomsten (zie ook Figuur B3.1).

- Gegeven dat men tevreden is met de voorbereiding om te starten op de arbeidsmarkt:

0 het verschil tussen tevreden zijn met de aansluiting en ontevreden zijn met de aansluiting wordt sterk bepaalt door vakkennis en de hieraan verbonden horizontale aansluiting tussen opleiding en gevonden werk;

- Gegeven dat men tevreden is met de aansluiting tussen opleiding en werk:

0 het verschil tussen tevreden zijn met de voorbereiding en ontevreden zijn met de voorbereiding wordt bepaald door een breder set aan generieke competenties opgedaan in het mbo en slechts marginaal door een horizontale of verticale match. 
TEKSTBOX 3 MBO: Samenhang tussen voorbereiding en aansluiting: Nadere analyses

FIGUUR B3.1 Relatie tussen tevredenheid en FIGUUR B3.2 Relatie tussen tevredenheid en opleiding-werk match (log-odds ratios) eigen niveau aan competenties (log-odds ratios)
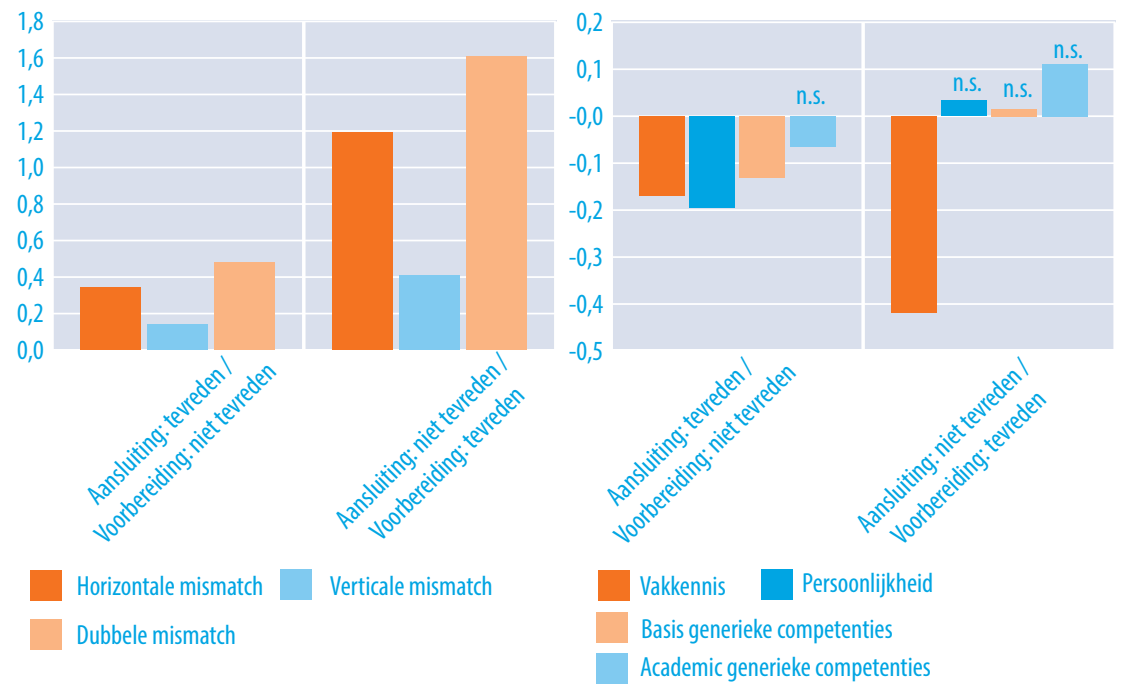

Bron: MBO-Monitor (ROA): 2011-2014

Noot: n.s. = niet significant

\section{Doorstroom naar arbeidsmarkt: de rol van de match tussen functie en opleiding}

Het rendement en de kwaliteit van een studie wordt mede bepaald door de mate waarin men werkt in een functie die zowel qua richting als niveau aansluit bij de gevolgde opleiding. Sommige opleidingen zijn weliswaar specifieker (bijvoorbeeld mbo verpleegkundige) en sommige zijn breder (bijvoorbeeld mbo administratief medewerker), maar in de regel zal de aansluiting beter zijn wanner de functie dicht bij de gevolgde opleiding ligt. In andere woorden, er mag aangenomen worden dat tijdens de studie verworven kennis en vaardigheden beter tot hun recht komen in beroepen die ook aansluiten bij de gevolgde studie. In het kader van het voorliggende onderzoek is het interessant om na te gaan of dit ook geldt voor de voorbereiding die een mbo-opleiding biedt als basis om te starten op de arbeidsmarkt. Hiervoor zijn op basis van de zelfinschatting van de respondenten de beroepen waarin ze werkzaam zijn in een viertal domeinen onderverdeeld:

- Kerndomein: werkzaam in een functie die zowel qua niveau als qua richting bij de gevolgde opleiding past; 
- Horizontale mismatch: werkzaam in een functie die qua niveau bij de opleiding past maar niet qua richting;

- Verticale mismatch: werkzaam in een functie die qua niveau onder het niveau van de opleiding ligt maar qua richting wel bij de opleiding past;

- Dubbele mismatch: werkzaam in een functie die zowel qua niveau als qua richting niet bij de opleiding past.

FIGUUR 4.2 Voorbereiidng en aansluiting: horizontale en verticale match
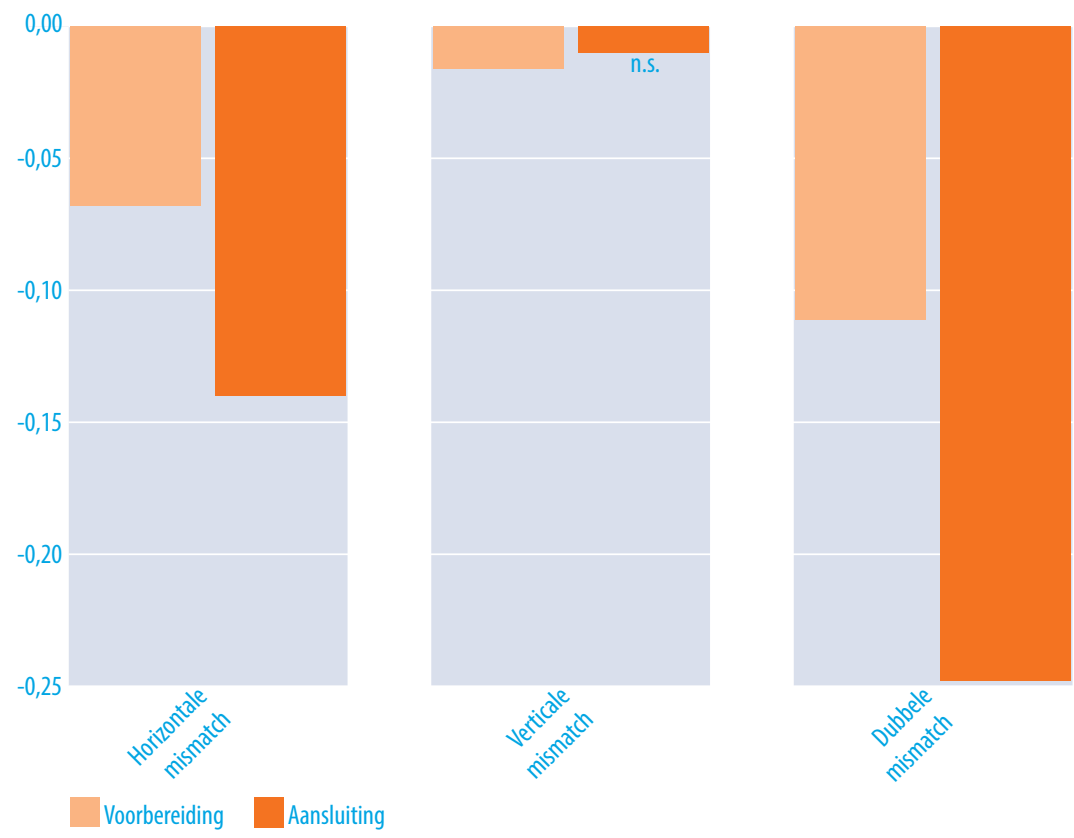

Bron: MBO-Monitor (ROA): 2011-2014

Noot: n.s. $=$ niet significant

Figuur 4.2 laat de gestandaardiseerde coëfficiënten zien met betrekking tot het hebben van een van de drie mogelijke mismatches (het kerndomein is daarbij als referentie gekozen). Niet verrassend vinden we dat alle drie type van mismatches een negatieve impact kennen op het oordeel wat zowel de aansluiting als de voorbereiding betreft. Kijken we echter in meer detail, dan zien we een tweetal interessante uitkomsten: Het oordeel over voorbereiding en aansluiting wordt vooral beïnvloedt door een horizontale mismatch, zij het in combinatie met een baan op eigen niveau dan wel in combinatie met een baan onder het eigen niveau; en de negatieve invloed van een horizontale mismatch (enkel horizontale mismatch of dubbele mismatch) op de aansluiting is 2 tot bijna 3 keer zo sterk als op de voorbereiding. Deze twee uitkomsten lijken, vergelijkbaar met de resultaten op basis van de doorstroom naar het vervolgonderwijs, erop te duiden dat voorbereiding om te starten op de arbeidsmarkt een breder pallet aan 
vaardigheden en competenties betreft dan wat respondenten in gedachte hebben bij de aansluiting. Of dit wederom gebaseerd is op een verschil in de rol en de waarde van vakkennis versus generieke competenties is de vraag die we in het vervolg gaan stellen.

\section{Doorstroom naar arbeidsmarkt: de rol van competenties}

De MBO-Monitor vragenlijst kent een uitgebreide lijst van competenties. Respondenten worden daarbij gevraagd om voor verschillende items op een 5-punt Likert schaal aan te geven in hoeverre het item van belang is voor goed uitoefenen van de huidige functie en in welke mate ze een item beheersen. We volgen in het voorliggende onderzoek recent onderzoek (zie ROA (2014a en 2014b)) en groeperen de items in een viertal clusters van competenties met de volgende onderliggende items:

Vakkennis (Cronbach alpha: 0.75)

- Vakkennis

- Toepassen van kennis en technieken in de praktijk

Persoonlijkheid (Cronbach alpha: 0.86)

- Zelfstandigheid

- Initiatief, creativiteit

- Aanpassingsvermogen

- Nauwkeurigheid, zorgvuldigheid

Basis generieke competenties (Cronbach alpha: 0.56)

- Schrijfvaardigheid

- Spreekvaardigheid

\section{Geavanceerde generieke competenties (Cronbach alpha: 0.80)}

- Inzicht in informatie- \& communicatietechnologie (incl. computergebruik)

- Overdragen van kennis

- Plannen, coördineren, organiseren van activiteiten

- Contactuele vaardigheden

- Werken in teamverband / samenwerken

Om te starten laat Figuur 4.3 de relatie tussen de vier competentieclusters (op basis van het eigen niveau aan competenties) en het oordeel wat de voorbereiding om te starten op de arbeidsmarkt en de aansluiting tussen de functie en de gevolgde opleiding zien (gestandaardiseerde coëfficiënten). De basis om te starten op de arbeidsmarkt ('voorbereiding') is daarbij positief gecorreleerd met drie van de vier clusters (vakkennis, persoonlijkheid items en basis generieke competenties). De coëfficiënten zijn daarbij van vergelijkbare hoogte. Alleen het eigen niveau van de geavanceerde generieke competenties kent geen significante relatie met onze indicator voor de voorbereiding. Wat de aansluiting betreft, zien we een tweetal clusters die een significante impact hebben. Een hoger niveau aan vakkennis gaat gepaard met een hogere tevredenheid 
wat de aansluiting betreft. Het effect is daarbij zo'n 3 keer hoger dan van vakkennis op de voorbereiding. Daar tegenover staat dat een hoger niveau aan geavanceerde generieke competenties een negatieve correlatie met de aansluiting kent. Deze bevindingen zijn in lijn met eerder onderzoek (zie bijvoorbeeld Meng, 2006) welke liet zien dat vakkennis vooral van waarde is indien men in een functie binnen het eigen domein (horizontale match) terecht komt. Geavanceerde generieke competenties kennen daarentegen vooral waarde indien men buiten het eigen domein (horizontale mismatch) terecht komt. Zoals boven aangetoond is het oordeel over de aansluiting sterk beïnvloedt door het wel of niet hebben van een horizontale match. Het feit dat vakkennis en geavanceerde generieke competenties daarnaast nog een afzonderlijk effect kennen kan erop duiden dat er binnen de vier onderscheiden domeinen nog verdere heterogeniteit bestaat wat de rol van vakkennis (binnen het eigen domein) en geavanceerde generieke competenties (buiten het eigen domein) betreft.

Tot slot kan vastgesteld worden dat de bevindingen met betrekking tot de competenties redelijk in lijn liggen met onze eerdere bevindingen over competenties en hun samenhang met de voorbereiding op en aansluiting met vervolgonderwijs. Ook daar hebben we namelijk gezien dat de aansluiting vooral door vakkennis gedragen wordt, terwijl de voorbereiding een relatie met een breder pallet van competenties kent.

FIGUUR 4.3 Voorbereiding en aansluiting: eigen niveau aan competenties
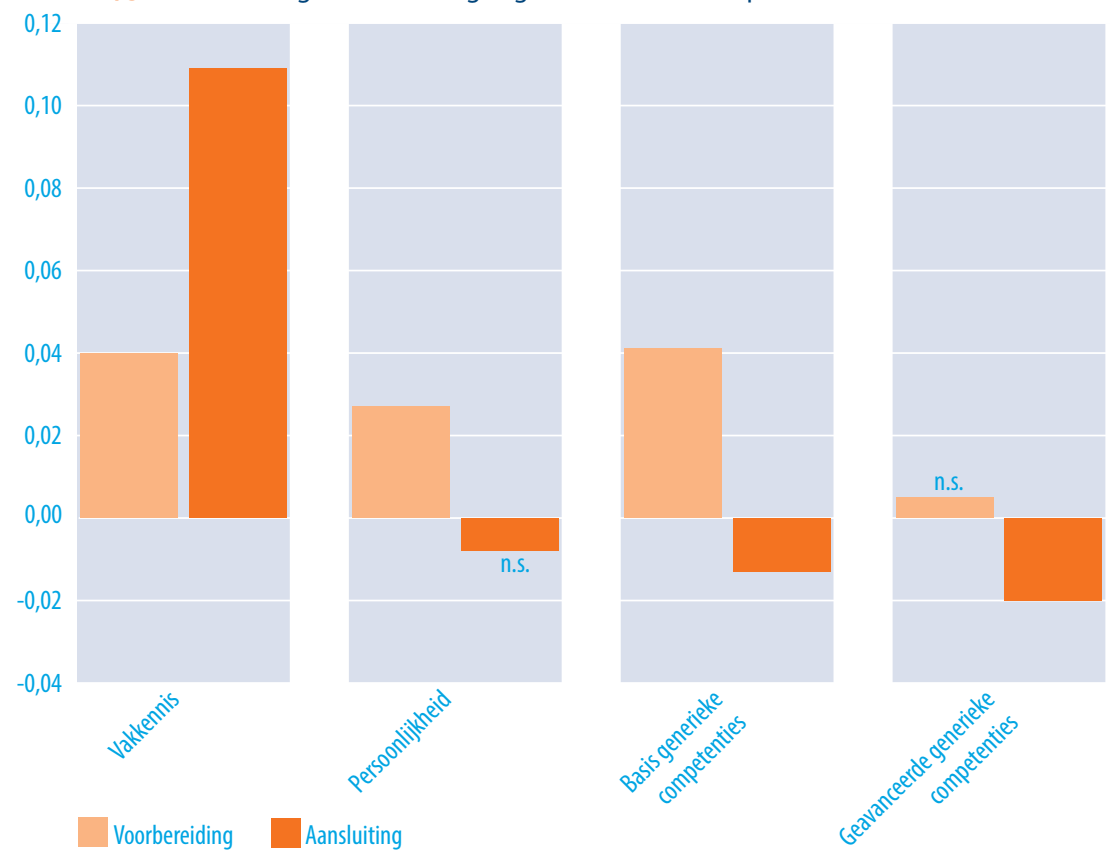

Bron: MBO-Monitor (ROA): 2011-2014

Noot: n.s. = niet significant 
Naast het feit dat we het eigen niveau aan competenties in de MBO-Monitor kunnen meten, biedt deze data de mogelijkheid om eventuele tekorten of overschotten met betrekking tot de competentieclusters vast te stellen. ${ }^{16}$ Figuur 4.4 laat de gestandaardiseerde coëfficiënten afkomstig van de multivariate analyse zien met betrekking tot deze tekorten en overschotten. Kort samengevat zijn de belangrijkste bevindingen als volgt: Ten eerste zijn alle significante effecten negatief. Met andere woorden, zowel een tekort als een overschot aan competenties is in de regel negatief gecorreleerd met het oordeel wat de voorbereiding of de aansluiting betreft. Daarnaast kent slechts een beperkte set aan competentie mismatches (overschot aan vakkennis en overschot aan persoonlijkheid) een negatieve relatie met het oordeel over de voorbereiding. Dit in tegenstelling tot de bevindingen wat het eigen niveau betreft. Als laatste valt op te merken dat alle competentie mismatches (zowel overschot als tekort) negatief gecorreleerd zijn met het oordeel wat de aansluiting betreft.

FIGUUR 4.4 Voorbereiding en aansluiting: overschot en tekort aan competenties

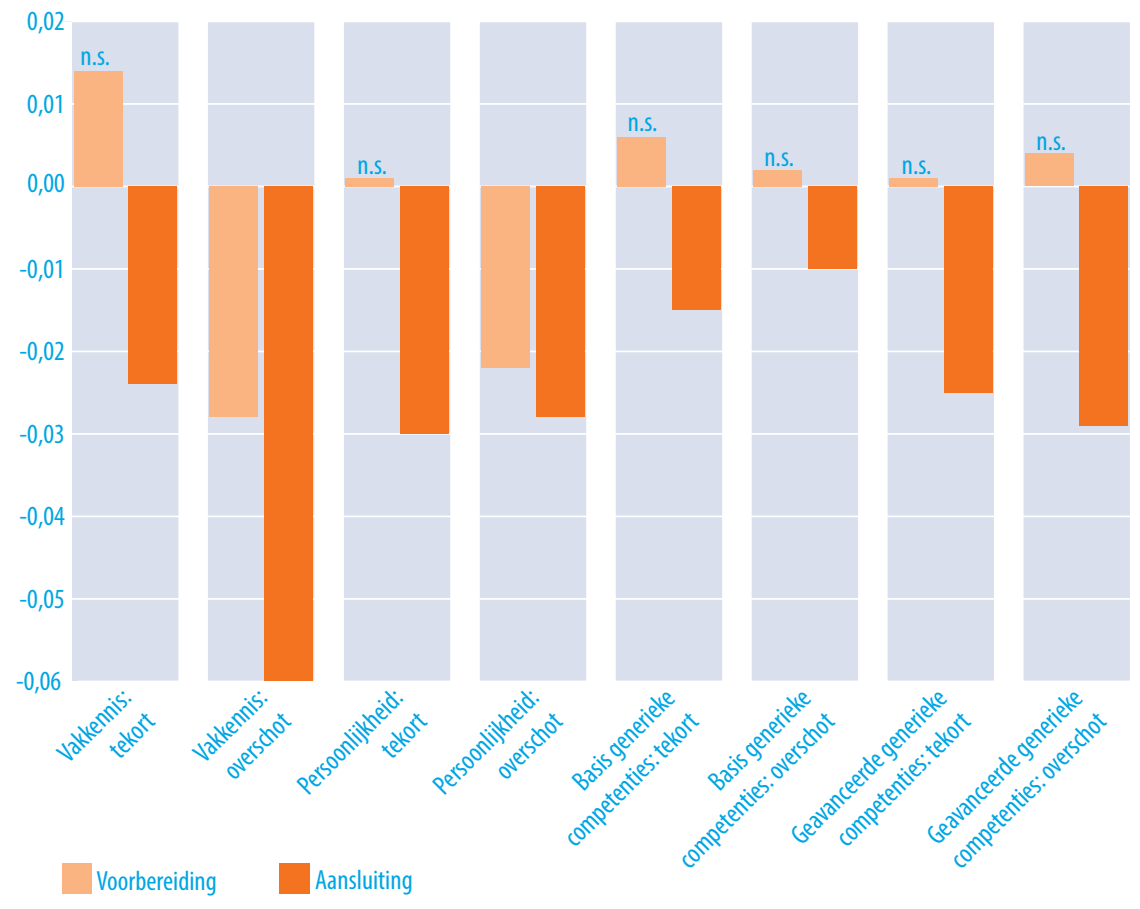

Bron: MBO-Monitor (ROA): 2011-2014

Noot: n.s. = niet significant

16 Een overschot wordt daarbij gedefinieerd als een hoger eigen niveau dan het in de functie vereiste niveau. In het geval van een tekort is het eigen niveau lager dan het vereiste niveau. 
Tot slot van deze paragraaf staan we stil bij de uitkomsten van de multivariate analyses met betrekking tot andere oordelen van de werkende mbo'ers over de gevolgde opleiding. Figuur 4.5 presenteert de gestandaardiseerde coëfficiënten. Vergelijkbaar met onze bevindingen over de doorstroom naar het vervolgonderwijs zien we dat een positief oordeel over de voorbereiding op het werk en de aansluiting van het werk met de gevolgde opleiding ook tot positieve oordelen over andere aspecten van de opleiding leidt. De sterkste relatie is daarbij te vinden met de indicator 'mbo-opleiding was te smal' (deze is inderdaad negatief zowel voor voorbereiding als aansluiting) en de tevredenheid met de voorlichting over beroepsmogelijkheden. Kijken we nader of zich verschillen voordoen tussen de impact op de indicator met betrekking tot voorbereiding en de indicator met betrekking tot aansluiting, dan zien we dat, weliswaar relatief kleine, verschillen zichtbaar zijn bij een tweetal andere oordelen. Ten eerste is het oordeel over de voorlichting met betrekking tot beroepsmogelijkheden sterker gecorreleerd met de voorbereiding dan met de aansluiting. Hetzelfde geldt voor het oordeel over de selectiviteit van de mbo-opleiding. Ten tweede is een te brede mboopleiding positief gecorreleerd met de indicator 'voorbereiding' maar negatief met de indicator voor 'aansluiting'. Een brede opleiding lijkt de mogelijkheid te bieden om in verschillende beroepen terecht te komen en kan daarmee de basis om te starten op de arbeidsmarkt verhogen. Tegelijkertijd zal een (te) brede opleiding een minder goede aansluiting met het daadwerkelijk gevonden werk kunnen bieden.

Samenvattend kan tot nu toe geconcludeerd worden dat:

- Het oordeel over voorbereiding en aansluiting vooral beïnvloedt wordt door een horizontale mismatch, zij het in combinatie met een baan op eigen niveau dan wel in combinatie met een baan onder het eigen niveau;

- De negatieve invloed van een horizontale mismatch (enkel horizontale mismatch of dubbele mismatch) op de aansluiting is 2 tot bijna 3 keer zo sterk als op de voorbereiding.

- Net zoals eerder is waargenomen, is ook bij het mbo de aansluiting op de arbeidsmarkt vooral beïnvloed door vakkennis, terwijl de voorbereiding een relatie met een breder pallet van competenties kent.

- Zowel een tekort als een overschot aan competenties is in de regel negatief gecorreleerd met het oordeel wat de voorbereiding of de aansluiting betreft. 
FIGUUR 4.5 Voorbereiding en aansluiting: relatie met andere oordelen
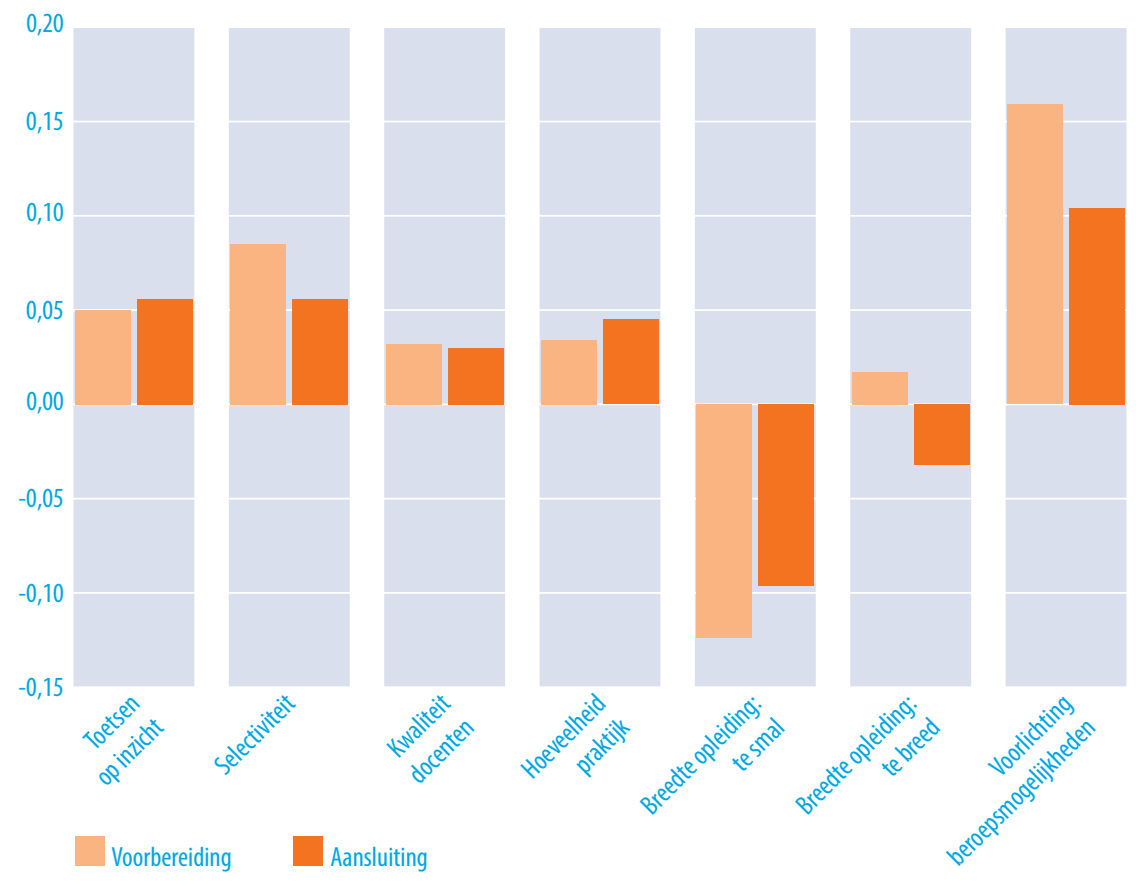

Bron: MBO-Monitor (ROA): 2011-2014

Noot: n.s. = niet significant

\section{Doorstroom naar arbeidsmarkt: verschil tussen mbo-bol en mbo-bbl}

De bovenstaande analyses hebben aangetoond dat zich zowel wat de indicator 'voorbereiding' als wat de indicator 'aansluiting' betreft een duidelijk verschil voordoet tussen de gediplomeerden van het mbo-bol en de gediplomeerden van het mbo-bbl. Voor beide indicatoren geldt dat de gediplomeerden van het mbo-bbl significant tevredener zijn. De vraag is of zich in de relatie tussen de twee indicatoren aan de ene kant en de andere uitkomstmaten, zoals gemeten in de MBO-Monitor, eveneens verschillen voordoen tussen de gediplomeerden van de twee leerwegen. Hiervoor zijn de analyses afzonderlijk voor de gediplomeerden van de twee leerwegen uitgevoerd. De resultaten zijn in de regel eenduidig: Er doen zich geen verschillen voor tussen de twee leerwegen wat de correlatie betreft tussen voorbereiding/aansluiting aan de ene kant en bijvoorbeeld competenties (eigen niveau, tekorten en overschotten), verticale/horizontale match tussen opleiding en functie of andere oordelen aan de andere kant. Met andere woorden, de uitkomsten zoals boven gepresenteerd zijn in de regel ook van toepassing op de twee afzonderlijke leerwegen. 


\section{2 hbo naar arbeidsmarkt}

De analyses wat de intrede op de arbeidsmarkt betreft hebben tot zover laten zien dat voor de mbo-gediplomeerden de indicatoren 'voorbereiding' en 'aansluiting' op een aantal punten als twee duidelijk verschillende concepten dienen opgevat te worden. In deze paragraaf analyseren we de twee indicatoren zoals gemeten in de HBO-Monitor. Daarmee willen we achterhalen of deze bevindingen ook voor de afgestudeerden van het hbo gelden. We bespreken hierbij dezelfde concepten (arbeidsmarktdomeinen, competenties en andere oordelen) als bij het mbo op basis van een tweetal multivariate analyses waarbij de afhankelijke variabelen overeenkomen met de twee indicatoren zoals ook gemeten in de MBO-Monitor: 'voorbereiding om te starten op de arbeidsmarkt' en 'aansluiting van functie met gevolgde opleiding'.

TEKSTBOX 4 HBO: Samenhang tussen voorbereiding en aansluiting: Nadere analyses

Tabel B4.1 laat zien dat 43\% van de werkzame gediplomeerde van het hbo zowel wat de aansluiting als wat de voorbereiding betreft tevreden is. Nog eens $29 \%$ is weliswaar tevreden met de aansluiting maar niet met de voorbereiding. Een en op de vijf is uiteindelijk zowel wat de voorbereiding betreft als wat de aansluiting betreft ontevreden. Wat de verschillende subgroepen betreft, komen weinig grote verschillen naar voren. Slechts op twee punten zijn duidelike verschillen zichtbaar:

- de gediplomeerden van de sector Techniek zijn duidelijk bovengemiddeld tevreden wat zowel de aansluiting als voorbereiding betreft;

- de gediplomeerden van de sector Economie en de sector Gedrag \& Maatschappij zijn bovengemiddeld vaak ontevreden over zowel de aansluiting als de voorbereiding.

TABEL B4.1 Tevredenheid per subgroepen (\%)

\begin{tabular}{|l|c|c|c|c|c|} 
& $\begin{array}{l}\text { Voorbereiding: } \\
\text { Ontevreden } \\
\text { Aansluiting: } \\
\text { Ontevreden }\end{array}$ & $\begin{array}{l}\text { Voorbereiding: } \\
\text { Tevreden } \\
\text { Aansluiting: } \\
\text { Ontevreden }\end{array}$ & $\begin{array}{l}\text { Voorbereiding: } \\
\text { Ontevreden } \\
\text { Aansluiting: } \\
\text { Tevreden }\end{array}$ & $\begin{array}{l}\text { Voorbereiding: } \\
\text { Tevreden } \\
\text { Aansluiting: } \\
\text { Tevreden }\end{array}$ & \\
\hline HBO Totaal & 21 & 7 & 29 & 43 & $100 \%$ \\
\hline Landbouw & 23 & 8 & 20 & 49 & $100 \%$ \\
\hline Onderwijs & 15 & 4 & 34 & 47 & $100 \%$ \\
\hline Techniek & 15 & 7 & 24 & 54 & $100 \%$ \\
\hline Economie & 25 & 8 & 27 & 40 & $100 \%$ \\
\hline Gezondheidszorg & 14 & 4 & 34 & 48 & $100 \%$ \\
\hline Gedrag \& Maatschappij & 29 & 7 & 34 & 30 & $100 \%$ \\
\hline
\end{tabular}

Bron: HBO-Monitor 2011-2014 
In aanvulling aan de analyses die in het rapport besproken zijn en de beschrijvende resultaten zoals in Tabel B4.1 gepresenteerd, zijn multinomiale analyses uitgevoerd op de vier combinaties (zie Tabel B4.1.) wat de tevredenheid met voorbereiding en aansluiting betreft (basis = tevreden met voorbereiding en tevreden met aansluiting). Voor een overzicht van de meegenomen controlevariabelen, zie Bijlage $V$. Deze bevestigen de resultaten zoals in het rapport besproken met als centrale uitkomsten (zie ook Figuur B4.1).

- Gegeven dat men tevreden is met de voorbereiding om te starten op de arbeidsmarkt:

0 het verschil tussen tevreden zijn met de aansluiting en ontevreden zijn met de aansluiting wordt sterk bepaald door vakkennis en de hieraan verbonden horizontale aansluiting tussen opleiding en gevonden werk (eventueel in combinatie met een verticale mismatch);

- Gegeven dat men tevreden is met de aansluiting tussen opleiding en werk:

0 het verschil tussen tevreden zijn met de voorbereiding en ontevreden zijn met de voorbereiding wordt aanzienlijk minder bepaald door door vakkennis en de hieraan verbonden horizontale aansluiting tussen opleiding en gevonden werk (eventueel in combinatie met een verticale mismatch).

FIGUUR B4.1 Relatie tussen tevredenheid en FIGUUR B4.2 Relatie tussen tevredenheid en opleiding-werk match (log-odds ratios) eigen niveau aan competenties (log-odds ratios)
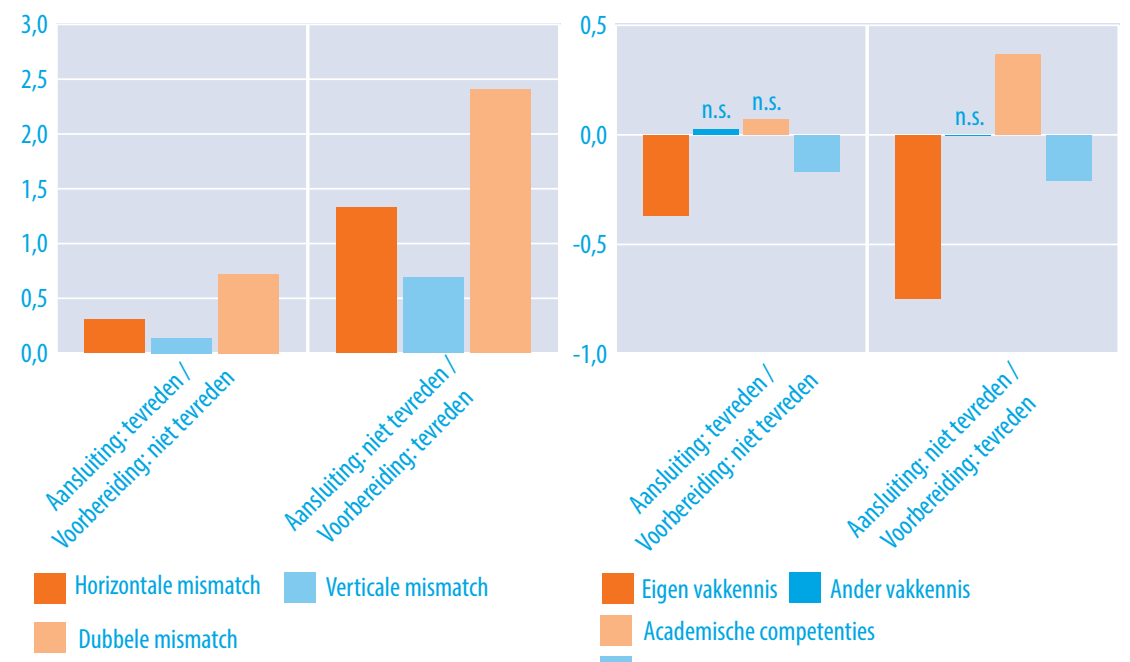

Bron: HBO-Monitor 2011-2014

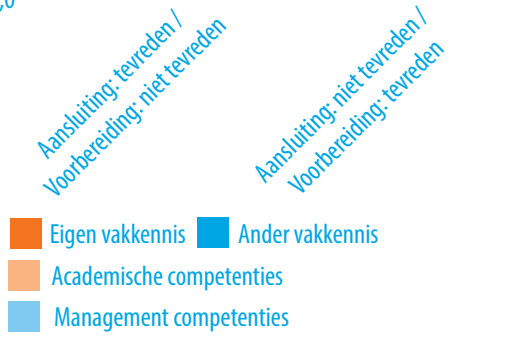

Noot: n.s. = niet significant 
Wat de arbeidsmarktdomeinen van de hbo afgestudeerden betreft onderscheiden we wederom een viertal domeinen:

- Kerndomein: werkzaam in een functie die zowel qua niveau als qua richting bij de gevolgde opleiding past;

- Horizontale mismatch: werkzaam in een functie die qua niveau bij de opleiding past maar niet qua richting;

- Verticale mismatch: werkzaam in een functie die qua niveau onder het niveau van de opleiding ligt maar qua richting wel bij de opleiding past;

- Dubbele mismatch: werkzaam in een functie die zowel qua niveau als qua richting niet bij de opleiding past.

FIGUUR 4.6 Voorbereiding en aansluiting: horizontale en verticale match

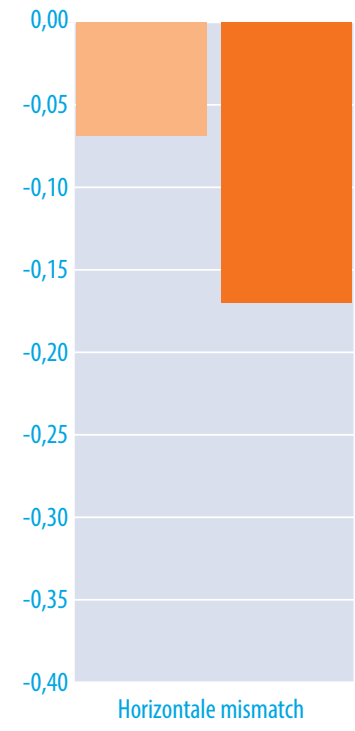

Voorbereiding

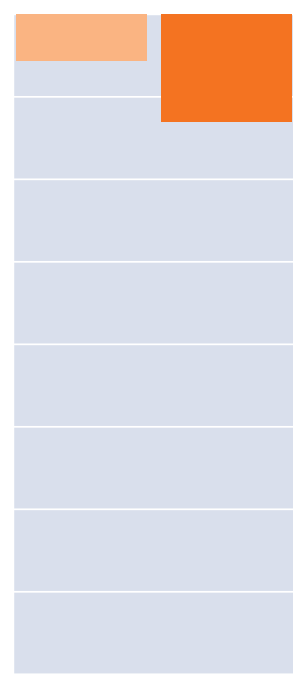

Verticale mismatch

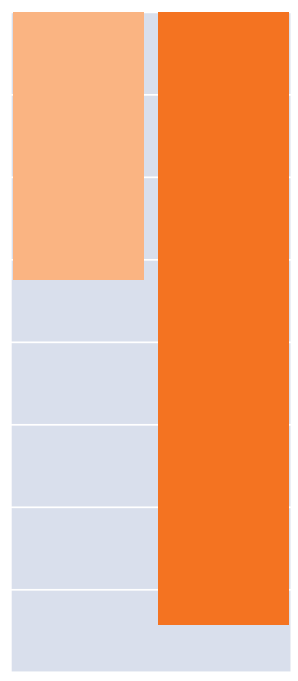

Dubbele mismatch

Aansluiting

Bron: HBO-Monitor (ROA): 2013-2014

Figuur 4.6 laat zien dat, conform de bevindingen onder de mbo-gediplomeerden, de hbo afgestudeerden welke buiten het eigen domein (horizontale mismatch of dubbele mismatch) terecht zijn gekomen zowel qua voorbereiding als qua aansluiting negatiever oordelen dan degenen die in het kerndomein terecht zijn gekomen. De grootte van de effecten, en de verhouding tussen de effecten op de indicator 'aansluiting' en de indicator 'voorbereiding' zijn daarbij sterk vergelijkbaar met de uitkomsten onder de mbo-gediplomeerden. Wat een pure verticale mismatch betreft zien we wederom 
dat de negatieve effecten duidelijk kleiner zijn, hoewel de effecten onder de afgestudeerden van het hbo iets groter zijn dan onder de gediplomeerden van het mbo. Dit zou erop kunnen duiden dat een verticale mismatch door hbo'ers sterker aangerekend wordt aan de gevolgde opleiding dan door mbo'ers, of dat een onderbenutting qua niveau voor hbo'ers grotere gevolgen kent dan voor mbo'ers ${ }^{17}$.

\section{Doorstroom naar arbeidsmarkt: de rol van competenties}

Vergelijkbaar met de MBO-Monitor kent ook de HBO-Monitor een uitgebreide lijst van competenties waarop de respondenten worden gevraagd om voor verschillende items op een 5-punt Likert schaal aan te geven in hoeverre het item van belang is voor goed uitoefenen van de huidige functie en in welke mate ze een item beheersen. Op basis van cluster- en factoranalyses is besloten een viertal clusters van competenties te onderscheiden met de volgende onderliggende items:

\section{Vakkennis (Cronbach alpha: 0.81)}

- Vakkennis

- Uw vakkennis in de praktijk toe te passen

\section{Andere vakkennis}

- Kennis van andere vakgebieden

Academische competenties (Cronbach alpha: 0.84)

- Informatie- \& communicatietechnologieën te gebruiken

- Informatie te vergaren

- Problemen en kansen te signaleren

- Nieuwe ideeën en oplossingen te bedenken

- Nieuwe dingen te leren

\section{Management competenties (Cronbach alpha: 0.80)}

- Logisch te redeneren

- Conform budget, planning of richtlijnen te werken

- Productief met anderen samen te werken

- Zelfstandig de werkzaamheden uit te voeren

- Analytisch te denken

Figuur 4.7 presenteert de gestandaardiseerde coëfficiënten met betrekking tot het eigen niveau van deze vier competentieclusters. Wat direct opvalt, is dat een tweetal clusters negatief gecorreleerd zijn met onze twee indicatoren 'voorbereiding' en 'aansluiting', namelijk 'kennis van andere vakgebieden' en de 'academische vaardigheden'. Wat de academische vaardigheden betreft komt dit overeen met onze bevindingen onder de

17 Bij mbo'ers kan onder het eigen niveau werken een terugval van 1 jaar school betekeken (bijvoorbeeld van mbo niveau 4 naar mbo niveau 3). Bij hbo'ers is het minimaal 4 jaar, gezien een hbo-opleiding bovenop een mbo-opleiding 4 jaar duurt. 
gediplomeerden van het mbo en kan erop duiden dat deze vooral in functies met een horizontale mismatch van toegevoegde waarde zijn. Dit geldt natuurlijk automatisch ook voor de kennis van andere vakgebieden. Daarnaast geldt ook hier dat de beide indicatoren, maar zeker de indicator 'aansluiting', sterk samenhangen met het eigen niveau aan vakkennis.

FIGUUR 4.7 Voorbereiding en aansluiting: eigen niveau aan competenties
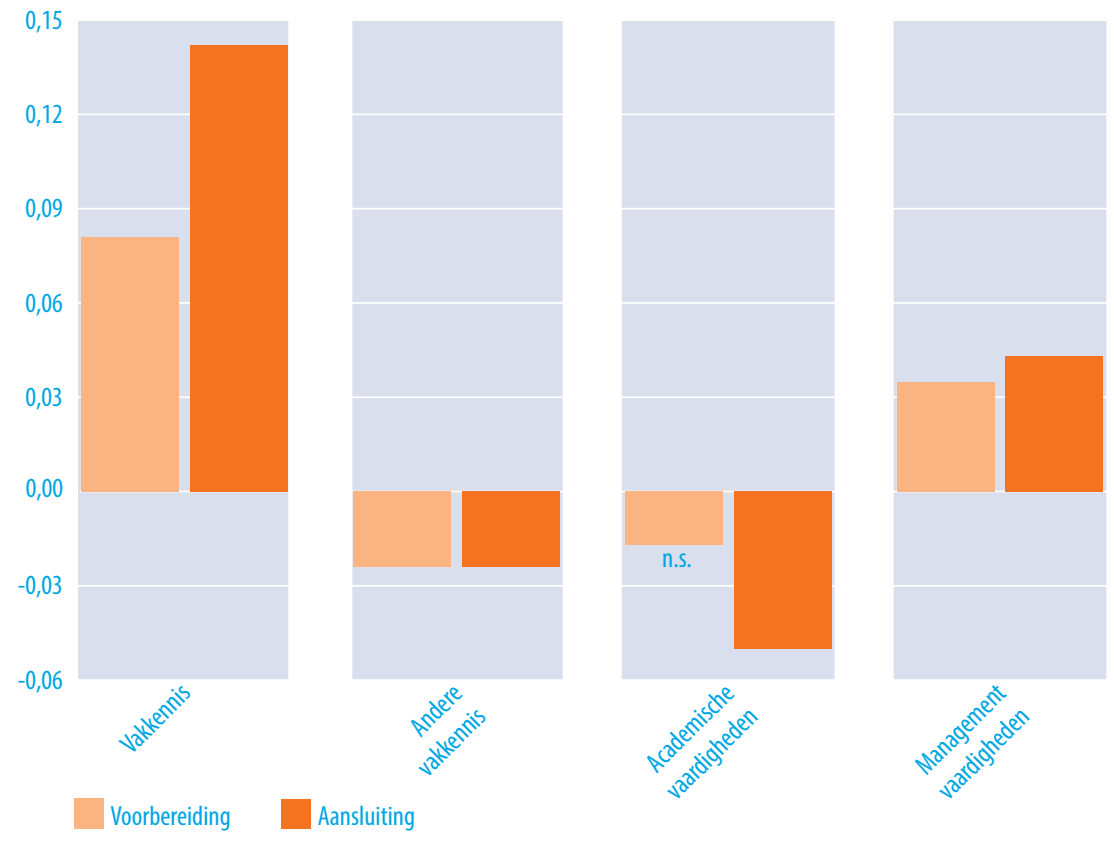

Bron: HBO-Monitor (ROA): 2013-2014

Noot: n.s. $=$ niet significant 
FIGUUR 4.8 Voorbereiding en aansluiting: competenties, tekorten en overschotten

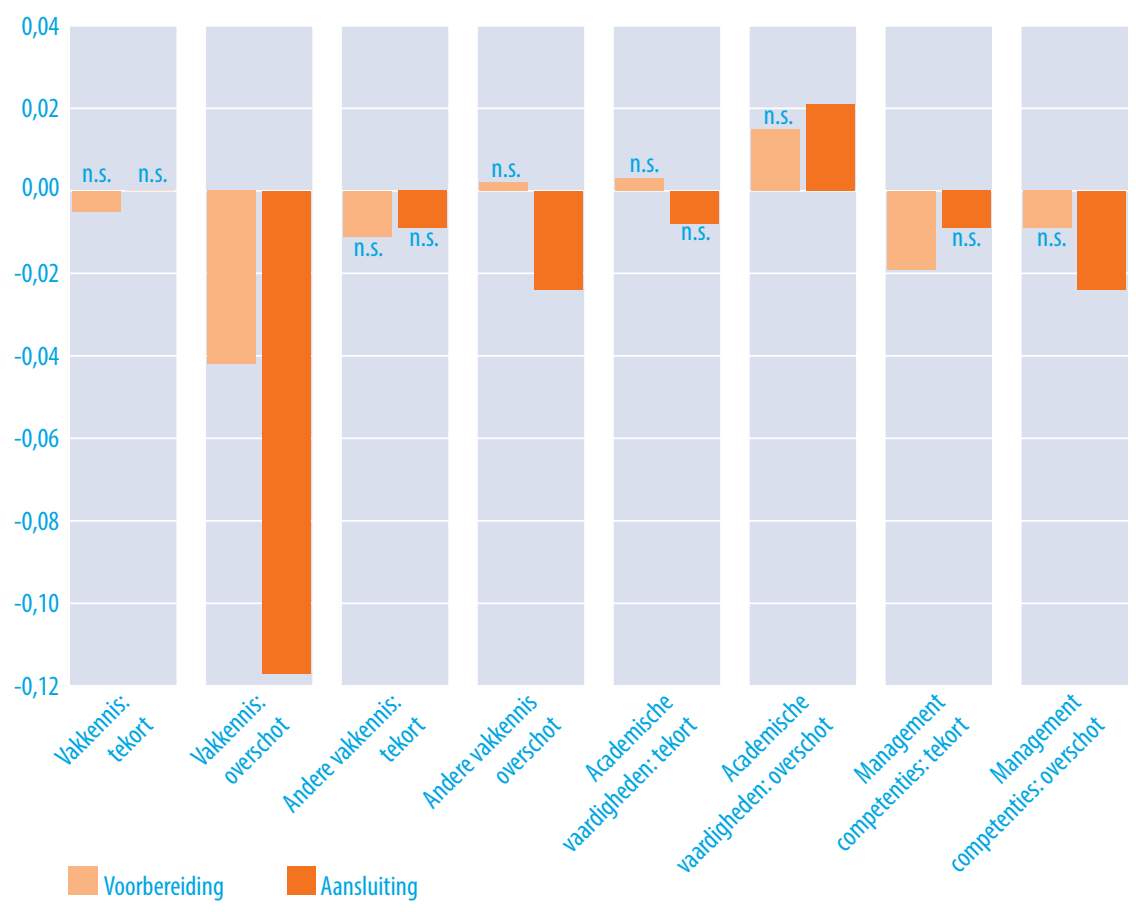

Bron: HBO-Monitor (ROA): 2013-2014

Noot: n.s. = niet significant

In een tweede stap staan we stil bij eventuele tekorten en overschotten wat deze competenties betreft (zie Figuur 4.8). Een tekort betekent daarbij dat het niveau dat in de functie vereist is hoger ligt dan het niveau dat de respondent zelf bezit, terwijl een overschot betekent dat qua competenties de respondent een hoger niveau bezit dan in de functie vereist wordt. Vergelijkbaar met de analyses onder de mbo-gediplomeerden zien we ook hier dat een mismatch in competenties vooral een effect heeft op de indicator 'aansluiting' en minder op de indicator 'voorbereiding.' Echter, terwijl bij de mbo-gediplomeerden zowel een overschot als een tekort het oordeel over de aansluiting negatief beïnvloedt, vinden we onder de afgestudeerden van het hbo dat in de regel alleen een overschot een significante negatieve impact heeft. Een tekort wordt daarmee niet direct als negatief punt aan de opleiding aangerekend. Dit zou kunnen betekenen dat voor hbo'ers een (klein) tekort aan competenties eerder gepaard gaat met het vinden van een functie waarin men kan groeien dan voor mbo'ers, en dat een tekort aan competenties bij hbo'ers hierdoor niet als negatief gezien wordt. 
De relatie met andere oordelen is onder hbo-afgestudeerden relatief sterk vergelijkbaar met wat we onder mbo-gediplomeerden hebben gevonden (zie Figuur 4.9). Een positief oordeel op de indicator 'voorbereiding' of de indicator 'aansluiting' gaat in de regel gepaard met een positief oordeel op andere aspecten wat de opleiding betreft. Het effect op de indicator 'voorbereiding' is daarbij altijd relatief sterker. Het sterkste effect vinden we wederom voor het oordeel 'tevredenheid met voorlichting over beroepsmogelijkheden' wat de waarde van goede voorlichting nog eens onderstreept.

FIGUUR 4.9 Voorbereiding en aansluiting: relatie met andere oordelen

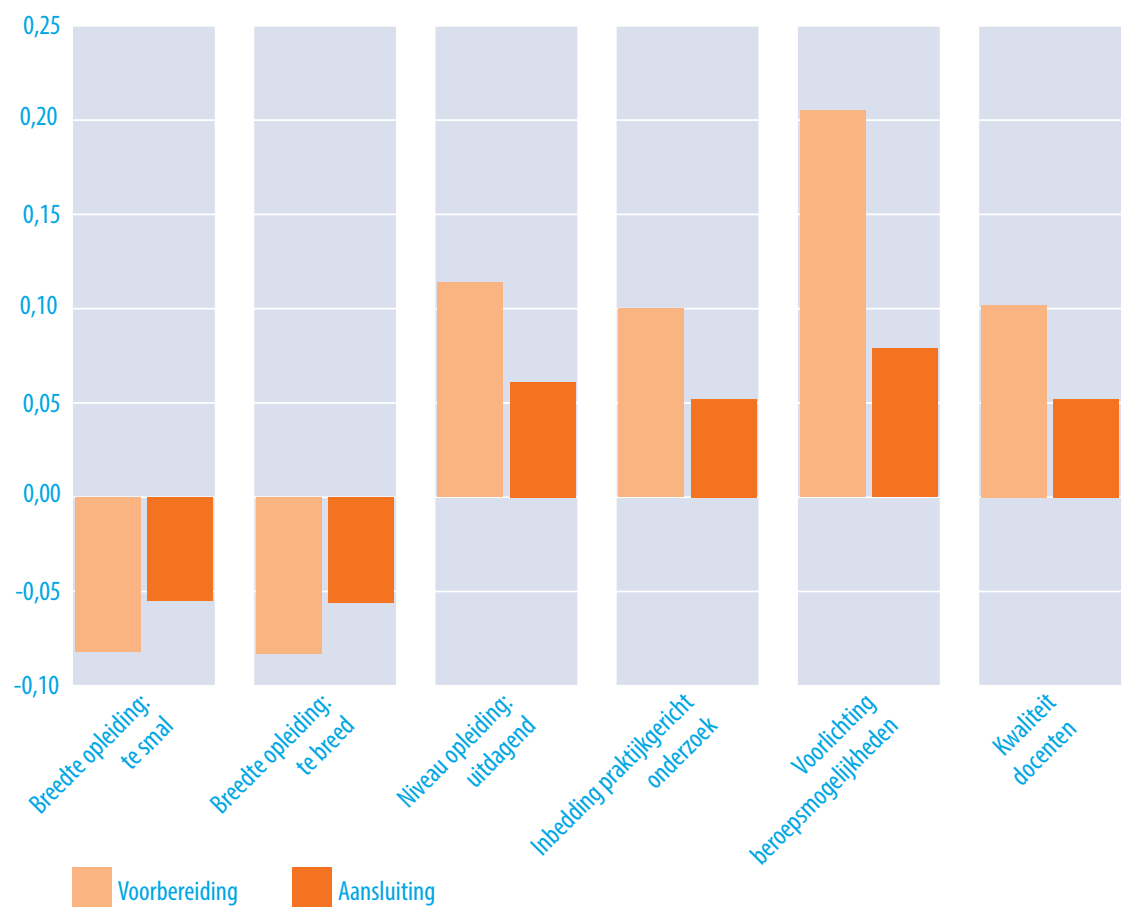

Bron: HBO-Monitor (ROA): 2013-2014

Noot: n.s. $=$ niet significant

Samenvattend kan geconcludeerd worden dat:

- Conform de bevindingen onder de mbo-gediplomeerden, oordelen de hbo-afgestudeerden welke buiten het eigen domein (horizontale mismatch of dubbele mismatch) terecht zijn gekomen zowel qua voorbereiding als qua aansluiting negatiever dan degenen die in het kerndomein terecht zijn gekomen.

- Bij een pure verticale mismatch zijn er grotere effecten dan bij gediplomeerden van het mbo. Dit zou erop kunnen duiden dat een verticale mismatch door hbo'ers 
sterker aangerekend wordt aan de gevolgde opleiding dan door mbo'ers of dat een onderbenutting qua niveau voor hbo'ers grotere gevolgen kent dan voor mbo'ers .

- Een tweetal clusters is negatief gecorreleerd met de twee indicatoren 'voorbereiding' en 'aansluiting', namelijk 'kennis van andere vakgebieden' en de 'academische vaardigheden'.

- Vergelijkbaar met de analyses onder de mbo-gediplomeerden zien we ook hier dat een mismatch in competenties vooral een effect heeft op de indicator 'aansluiting' en minder op de indicator 'voorbereiding'.

- Echter, terwijl bij de mbo-gediplomeerden zowel een overschot als een tekort het oordeel over de aansluiting negatief beïnvloedt, vinden we onder de afgestudeerden van het hbo dat in de regel alleen een overschot een significante negatieve impact heeft. Dit zou kunnen betekenen dat voor hbo'ers een (klein) tekort aan competenties eerder gepaard gaan gaat met het vinden van een functie waarin men kan groeien dan voor mbo'ers, en dat dit een tekort aan competenties hierdoor niet als negatief gezien wordt.

- De relatie met andere oordelen is onder hbo afgestudeerden relatief sterk vergelijk baar met wat we onder mbo-gediplomeerden hebben gevonden. 



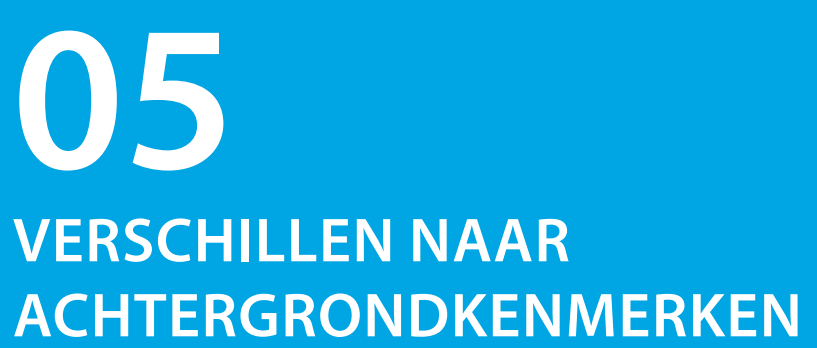

Tot zover heeft het rapport laten zien dat in de regel 'voorbereiding' en 'aansluiting' als twee verschillende (en deels overlappende) concepten gezien dienen te worden. In deze laatste paragraaf staan we stil bij de vraag of wat deze twee concepten betreft een verschil te vinden is tussen jongens en meisjes en tussen jongeren van niet-westerse herkomst en autochtone jongeren. Dat meisjes en jongeren van niet-westerse herkomst eventueel verschillen op deze twee aspecten kan samenhangen met verschillende factoren, zoals de manier waarop zij op deze leeftijd in het leven staan of de verwachtingen die zij hebben wat hun onderwijs- of arbeidsmarkt carrière betreft.

FIGUUR 5.1a Voorereiding en aansluiting: oordeel meisjes ten opzichte van jongens

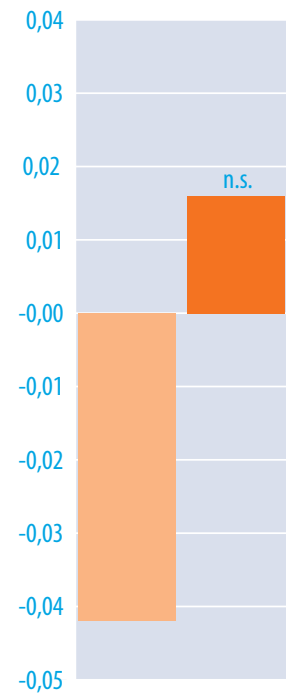

No

Voorbereiding
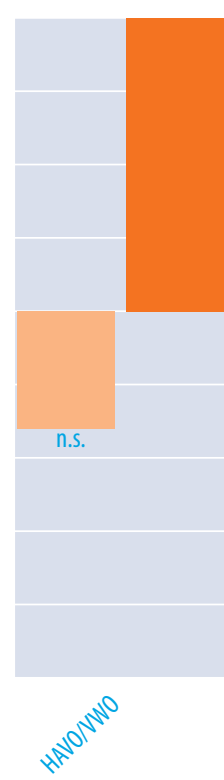

Aansluiting

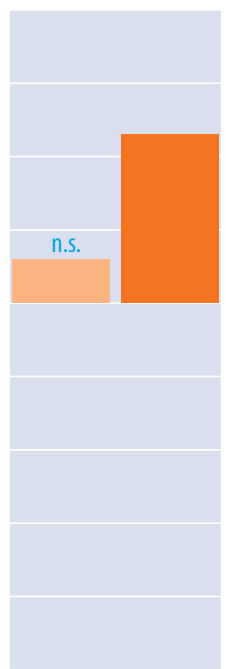

$\leqslant 0$

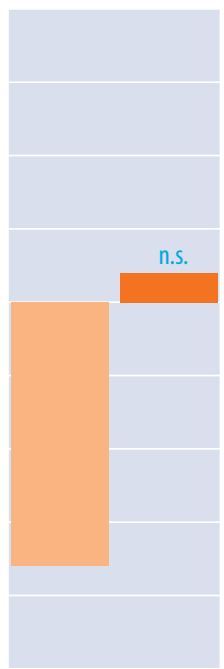

$<0$

Bron: VO-, MBO- en HBO-monitor (ROA); 2011-2014

Noot: n.s. = niet significant 
Figuur 5.1a laat de gestandaardiseerde coëfficiënten zien voor de dummy 'vrouwelijke respondent' afkomstig van de eerder in dit rapport gepresenteerde analyses. Figuur 5.1b doet dit voor de dummy 'niet-westerse allochtoon'. Deze uitkomsten zijn dan al, voor zover mogelijk, gecontroleerd voor factoren samenhangend met a) de gevolgde opleiding, b) de opgedane competenties en c) de gekozen vervolgopleiding / het gevonden werk.

De uitkomsten in Figuur 5.1a laten een interessant patroon zien. Meisjes zijn in de regel positiever over de aansluiting en tegelijkertijd negatiever over de voorbereiding. In eerste instantie onderstreept dit onze eerdere bevinding dat de twee concepten als aparte concepten gezien dienen te worden. Daarnaast kan dit erop duiden dat meisjes doelbewustere keuzes maken, wat zowel het vervolg in de onderwijsloopbaan als de arbeidsmarktintrede betreft. Deze doelbewustere keuzes kunnen tot een betere aansluiting leiden en een kritischere blik op de manier waarop de opleiding hen voorbereid heeft op het vervolgonderwijs dan wel het arbeidsmarktintrede. Verder onderzoek is echter zeker nodig om deze hypothesis te onderbouwen.

FIGUUR 5.1b Voorbereiding en aansluiting: oordelen niet-westerse allochtonen ten opzichte van autochtonen

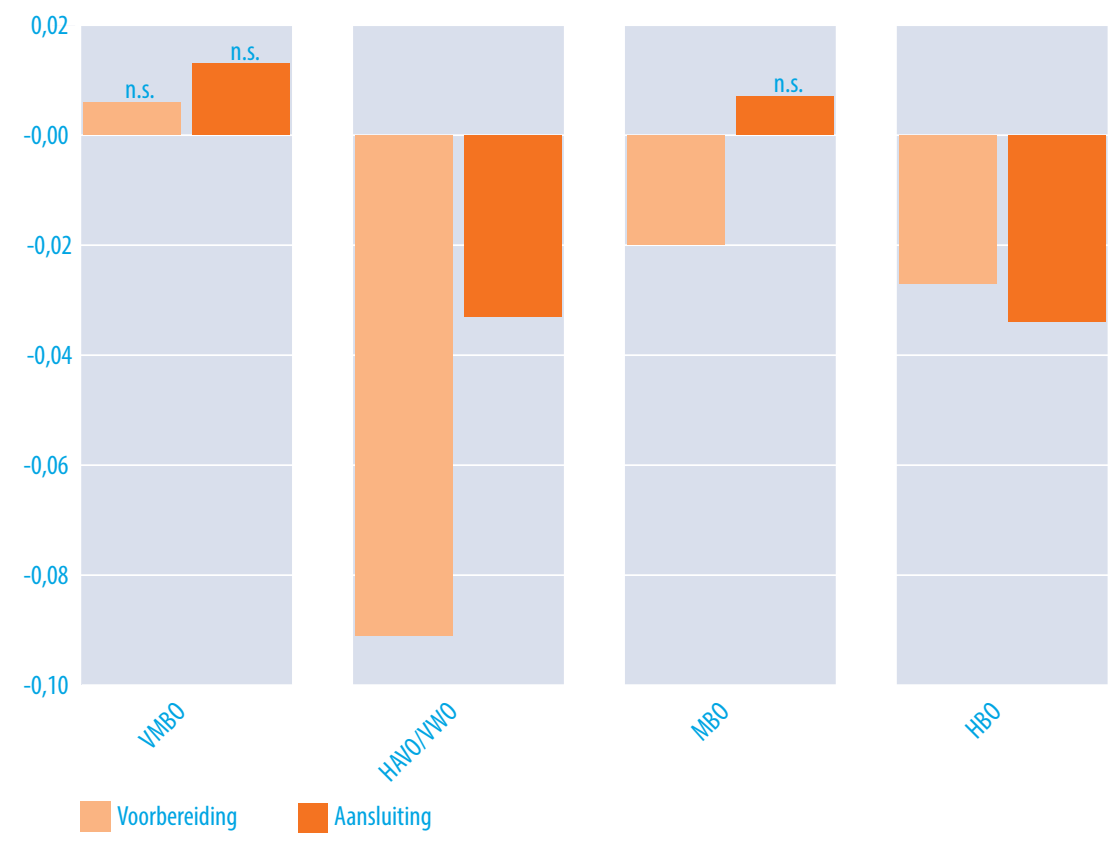

Noot: n.s. $=$ niet significant

Ook de uitkomsten in Figuur 5.1b laten een relatief duidelijk patroon zien. Jongeren van niet-westerse herkomst oordelen in de regel (de uitzondering zijn de gediplomeerden 
van het vmbo) negatiever wat de voorbereiding en de aansluiting betreft dan hun autochtone studiecollega's.

Wat de overstap van het havo/vwo naar het hoger onderwijs betreft is het interessant om hier in toekomst nader onderzoek na te verrichten. Hangt dit bijvoorbeeld samen met de verwachtingen die jongeren van niet-westerse herkomst van het hoger onderwijs hebben? Missen zij in de voorbereiding een aantal competenties welke van invloed zijn, maar niet opgenomen zijn in het onderzoek? Of speelt het relatief lagere onderwijsniveau van de ouders bij deze groep een rol in de studiekeuze, dat zich doorvertelt in het oordeel over voorbereiding en aansluiting?

Wat de voorbereiding op de arbeidsmarktintrede en de aansluiting tussen de gevolgde opleiding en het gevonden werk bij mbo'ers en hbo'ers, betreft kunnen de uitkomsten op een aantal aspecten duiden. Ten eerste dienen we er rekening ermee te houden dat de arbeidsmarkintrede van niet-westerse allochtonen, zeker in de recente economische crisis, aanzienlijk moelijker is verlopen dan het arbeidsmarktintrede van autochtone jongeren. ${ }^{18}$ Niet-westerse allochtonen dienen langer te zoeken en vaker te solliciteren naar een functie en kennen anderhalf jaar na afronden van de opleiding een grotere kans op werkloosheid. Ondanks dat we ons in de analyses tot de groep jongeren hebben beperkt die anderhalf jaar na afstuderen een baan hebben, kan deze moeilijkere start op de arbeidsmarkt tot een kritischere blik op zowel voorbereiding als aansluiting leiden. Het is interessant om in de volgende jaren, als de economie weer aantrekt, nader te onderzoeken of de problemen die de groep niet-westerse allochtonen ervaart kleiner worden of niet. In het tweede geval zou dit op een structureel probleem duiden dat een structurele oplossing vereist.

18 Zie bijvoorbeeld SCP, 2014. 



\section{6 \\ CONCLUSIES}

Voorbereiding op het vervolgonderwijs/de arbeidsmarkt en aansluiting tussen de afgeronde opleiding en de gekozen vervolgopleiding/de gevonden arbeidsmarkfunctie zijn een tweetal centrale concepten in het onderzoek onder gediplomeerde schoolverlaters. Een goede voorbereiding maar ook een goede aansluiting bepalen in sterke mate het succes van gediplomeerden in hun eerste stappen in het vervolgonderwijs dan wel op de arbeidsmarkt. Een centrale vraag is echter of jongeren een onderscheid maken wat deze twee concepten betreft en in hoeverre een onderscheid ook licht kan werpen op de vraag welke aspecten de tevredenheid met de voorbereiding en de aansluiting bepalen. Om op deze vraag nader in te gaan zijn in dit rapport een aantal analyses gepresenteerd op basis van het jaarlijkse onderzoek onder de gediplomeerden van het vmbo, het havo/ vwo, het mbo en de afgestudeerden van het hbo. Hierbij zijn de uitkomsten van een tweetal indicatoren in relatie gebracht met zowel objectieve als subjectieve onderwijsen arbeidsmarktuitkomsten gebracht:

- Voorbereiding op vervolgonderwijs / arbeidsmarkt

- Aansluiting met vervolgonderwijs / arbeidsmarktfunctie

De resultaten laten zien dat zich vooral een onderscheid manifesteert op basis van de vraag of de overgang in het kader van de beroepskolom plaatsvindt (vmbo $\rightarrow$ mbo $\rightarrow$ arbeidsmarkt / hbo $\rightarrow$ arbeidsmarkt) of in het kader van een meer algemene onderwijscarrière (havo/vwo $\rightarrow$ hoger onderwijs).

\section{Transities in de beroepskolom}

Voorbereiding op en aansluiting met het vervolgonderwijs / de arbeidsmarkt dienen als een tweetal, weliswaar gedeeltelijk overlappend, maar van elkaar te onderscheiden concepten opgevat te worden. Het centrale onderscheid is daarbij dat:

- 'Voorbereiding' te zien is als voorbereiding op een breed pallet van competenties (generieke competenties en vakkennis) die in het vervolgonderwijs / op de arbeidsmarkt gevraagd wordt.

- 'Aansluiting' wordt vooral bepaald door de aansluiting in vakkennis opgedaan tijdens de opleiding en eventuele tekorten in vakkennis. 
Dit verklaart dan ook waarom jongeren tamelijk kritisch kunnen oordelen over de voorbereiding, ondanks dat ze wat de aansluiting betreft relatief positief oordelen. Scholen dienen zich hiervan bewust te zijn en hun curriculum maar ook leeromgeving zodanig in te richten dat beide aspecten, namelijk een goede voorbereiding en een goede aansluiting, bereikt kunnen worden. Dit laat natuurlijk ook het spanningsveld zien waarmee het onderwijs in de beroepskolom geconfronteerd wordt. Immers, de tijd voor het aanleren van competenties in het onderwijs is beperkt en dient op een effectieve manier verdeeld te worden over generieke competenties en vakkennis. Eerder onderzoek (echter meestal gericht op het hoger onderwijs) heeft laten zien dat actieve leeromgevingen, zoals problem-based learning, hier een uitkomst voor kunnen bieden. Deze leeromgevingen stimuleren het aanleren van generieke competenties zonder dat een afbreuk dient plaats te vinden wat het aanleren van vakkennis betreft. Of deze uitkomsten echter ook voor opleidingen in het (v)mbo zo eenduidig is, is nog niet sluitend vastgesteld.

\section{Transities in het algemeen onderwijs}

Jongeren die vanuit het havo/vwo naar het hoger onderwijs overstappen lijken de twee concepten als sterk overlappende concepten te zien. In tegenstelling tot de overgangen in de beroepskolom speelt hier vakkennis geen bepalende factor. Met andere woorden, ook de aansluiting is vooral gebaseerd op generieke competenties welke in het hoger onderwijs vereist zijn om vakkennis aan te leren. Gezien vooral een tekort aan studieplanning vaardigheden, zelfstandig werken, initiatief nemen en informatie verzamelen en verwerken een negatieve impact op de tevredenheid met de 'voorbereiding' en 'aansluiting' kennen, is het van groot belang nader te onderzoeken op welke manier deze type competenties bij jongeren sterker gestimuleerd kunnen worden. 


\section{LITERATUUR}

Meng (2006), Discipline-Specific or Academic? Acquisition, Role and Value of Higher Education Competencies, Maastricht: Research Centre for Education and the Labour Market. ROA (2014a), Salarissen en competenties van MBO-BOL gediplomeerden: Feiten en cijfers, ROA-F-2014/1, Maastricht.

ROA (2014b), Schoolverlaters tussen onderwijs en arbeidsmarkt 2013, ROA-R-2014/5, Maastricht.

SCP (2014), Jaarrapport Integratie 2013, Den Haag. 



\section{BIJLAGEN}

BIJLAGE I Volledige resultaten vmbo

\begin{tabular}{|c|c|c|c|c|}
\hline & \multicolumn{2}{|c|}{ Voorbereiding } & \multicolumn{2}{|c|}{ Aansluiting } \\
\hline & Beta & Sign. & Beta & Sign. \\
\hline Constante & &, 000 & &, 000 \\
\hline Leeftijd &,- 018 & ,154 &,- 016 &, 236 \\
\hline Geslacht: vrouw &,- 042 & ,002 & 016 &, 270 \\
\hline Etniciteit: autochtoon & ref. & & ref, & \\
\hline Etniciteit: westerse allochtoon &,- 007 &, 579 & 016 &, 212 \\
\hline Etnicitieti: niet-westerse allochtoon &, 006 & ,633 &, 013 & 350 \\
\hline Meetjaar: 2012 &,- 009 & ,491 &,- 002 & 877 \\
\hline Meetjaar: 2013 &, 002 &, 869 &, 003 &, 836 \\
\hline Meetjaar: 2014 & ref. & & ref. & \\
\hline \multicolumn{5}{|l|}{ VMBO sector } \\
\hline Techniek &,- 010 &, 463 &,- 027 & ,077 \\
\hline Economie &, 020 & ,133 &, 005 &, 752 \\
\hline Gezondheidszorg &, 006 & ,677 &,- 007 & ,634 \\
\hline Intersectoraal &, 006 & ,753 &, 049 &, 013 \\
\hline Groen & ref. & & ref. & \\
\hline \multicolumn{5}{|l|}{ Leerweg } \\
\hline Kaderberoesbericht &, 008 &, 875 &,- 001 & ,989 \\
\hline Basisberoepsgericht &, 003 & ,950 &, 040 & 395 \\
\hline Theoretisch/gemengd &, 029 & ,602 & 047 &, 436 \\
\hline Leerwerk traject & ref. & & ref. & \\
\hline Verwante doorstroom vmbo - mbo &, 026 & ,083 &, 112 &, 000 \\
\hline MBO leerweg: BOL &, 003 &, 820 &, 018 & , 184 \\
\hline MBO niveau: $3 / 4$ &, 006 & ,731 & ,033 &, 094 \\
\hline Situatie in mbo: nog bezig & ref. & & ref. & \\
\hline Situatie in mbo: diploma behaald &, 012 & ,317 & ,009 & ,488 \\
\hline
\end{tabular}


BIJLAGE I Volledige resultaten vmbo

\begin{tabular}{|c|c|c|c|c|}
\hline & \multicolumn{2}{|c|}{ Voorbereiding } & \multicolumn{2}{|c|}{ Aansluiting } \\
\hline & Beta & Sign. & Beta & Sign. \\
\hline Situatie in mbo: gestopt &,- 110 &, 000 &,- 147 &, 000 \\
\hline \multicolumn{5}{|l|}{ Oordelen over vmbo } \\
\hline basis om competenties verder te ontwikkelen & ,125 &, 000 &, 074 &, 000 \\
\hline voldoende getoetst op inzicht & ,047 &, 001 &, 037 &, 015 \\
\hline selectiviteit vmbo* & ,041 &, 005 &, 033 &, 035 \\
\hline hoeveelheid praktijk &,- 001 & 969 &,- 001 & ,949 \\
\hline kwaliteit docenten & ,092 &, 000 &, 022 & 151 \\
\hline voorlichting over studiemogelijkheden & ,132 &, 000 & , 109 &, 000 \\
\hline breedte vmbo opleiding: te smal &,- 026 &, 040 &,- 032 &, 020 \\
\hline breedte vmbo opleiding: te breed &, 003 & 832 &, 006 & ,644 \\
\hline \multicolumn{5}{|l|}{ Voorbereiding competenties } \\
\hline zelfstandig werken & ,110 &, 000 &, 058 &, 000 \\
\hline samenwerken &,- 018 &, 222 & 011 & , 498 \\
\hline met de computer werken &, 029 & ,033 &, 033 &, 023 \\
\hline in de praktijk kunnen werken &, 074 &, 000 &, 028 & ,119 \\
\hline vakkennis & ,086 &, 000 & ,091 &, 000 \\
\hline Nederlandse taal &, 040 &, 012 &,- 015 & ,384 \\
\hline Engels & ,046 &, 002 &,- 006 & ,715 \\
\hline
\end{tabular}

* gemiddeld van een viertal aspecten 
BIJLAGE II Volledige resultaten havo / vwo

\begin{tabular}{|c|c|c|c|c|}
\hline & \multicolumn{2}{|c|}{ Voorbereiding } & \multicolumn{2}{|c|}{ Aansluiting } \\
\hline & Beta & Sign. & Beta & Sign. \\
\hline Constante & &, 000 & &, 000 \\
\hline leeftijd &,- 032 &, 061 &,- 015 & ,385 \\
\hline geslacht: vrouw &,- 016 & ,380 &, 040 &, 031 \\
\hline Etniciteit: autochtoon & ref. & & ref. & \\
\hline Etniciteit: westerse allochtoon & 013 &, 403 &, 022 & , 165 \\
\hline Etnicitieti: niet-westerse allochtoon &,- 033 &, 035 &,- 033 &, 040 \\
\hline Meetjaar: 2012 & ref. & & ref. & \\
\hline Meetjaar: 2012 &,- 019 & ,293 &,- 003 & ,877 \\
\hline Meetjaar: 2013 &, 000 & ,978 &, 005 &, 770 \\
\hline Meetjaar: 2014 &,- 014 &, 440 &, 022 & ,230 \\
\hline Vervolgopleiding: W0 & , 181 &, 000 & 130 &, 000 \\
\hline \multicolumn{5}{|l|}{ Profiel AV0 } \\
\hline EM &,- 060 &, 006 &,- 022 &, 326 \\
\hline$C M$ &,- 021 & ,326 &, 007 &, 730 \\
\hline NG &,- 038 &, 056 &,- 017 & ,393 \\
\hline NT &,- 045 &, 019 &, 013 &, 520 \\
\hline Combinatie & ref. & & ref. & \\
\hline verwante doorstroom &, 027 &, 096 &,- 004 &, 816 \\
\hline situatie in ho: nog bezig & ref. & & ref. & \\
\hline situatie in ho: diploma &, 020 & ,200 &, 051 &, 001 \\
\hline situatie in ho: gestopt &,- 116 &, 000 &,- 200 &, 000 \\
\hline \multicolumn{5}{|l|}{ Oordeel over avo } \\
\hline voldoende getoets op inzicht & ,103 &, 000 &, 091 &, 000 \\
\hline kwaliteit docenten & , 188 &, 000 &, 089 &, 000 \\
\hline breedte avo opleiding: te smal &,- 072 &, 000 &,- 035 &, 027 \\
\hline breedte avo opleiding: te breed &,- 033 &, 036 &,- 029 &, 065 \\
\hline selectiviteit avo* &, 072 &, 000 &, 067 &, 000 \\
\hline \multicolumn{5}{|l|}{ Competenties } \\
\hline zelfstandig werken: eigen niveau & ,077 &, 002 & ,083 &, 001 \\
\hline Zelfstandig werken: overschot &, 010 &, 567 &, 013 &, 471 \\
\hline Zelfstandig werken: tekort &,- 068 &, 002 &,- 072 &, 001 \\
\hline Creativiteit: eigen niveau &,- 041 &, 031 &,- 029 & ,136 \\
\hline Creativiteit: overschot &,- 015 &, 433 &,- 009 & ,650 \\
\hline Creativiteit: tekort &,- 032 & ,073 &,- 021 & ,242 \\
\hline
\end{tabular}


BIJLAGE II Volledige resultaten havo / vwo

\begin{tabular}{|c|c|c|c|c|}
\hline & \multicolumn{2}{|c|}{ Voorbereiding } & \multicolumn{2}{|c|}{ Aansluiting } \\
\hline & Beta & Sign. & Beta & Sign. \\
\hline Initiatief nemen: eigen niveau &,- 042 &, 052 &, 003 & ,907 \\
\hline Initiatief nemen: overschot &, 021 & ,234 &,- 001 & ,957 \\
\hline Initiatief nemen: tekort &,- 080 &, 000 &,- 046 &, 024 \\
\hline Communicatieve vaardigheden: eigen niveau &, 008 & ,701 &,- 029 & ,173 \\
\hline Communicatieve vaardigheden: overschot &,- 001 & 965 &,- 004 &, 832 \\
\hline Communicatieve vaardighende: tekort &, 004 &, 843 &,- 037 & ,065 \\
\hline Samenwerken: eigen niveau &, 050 &, 012 &, 049 & ,017 \\
\hline Samenwerken: overschot &,- 033 &, 057 &,- 061 &, 001 \\
\hline Samenwerken: tekort &, 010 &, 596 & ,019 & ,341 \\
\hline Studieplanning: eigen niveau &,- 005 &, 817 &, 002 & ,918 \\
\hline Studieplanning: overschot &,- 011 &, 531 &,- 026 & , 147 \\
\hline Studieplanning: tekort &,- 053 &, 012 &,- 069 &, 002 \\
\hline Informatie verzamelen en verwerken: eigen niveau &,- 014 & ,489 &,- 007 &, 725 \\
\hline Informatie verzamelen en verwerken: overschot &, 011 &, 534 &, 018 & ,305 \\
\hline Informatie verzamelen en verwerken: tekort &,- 053 &, 007 &,- 049 &, 014 \\
\hline Nederlands: eigen niveau &, 038 & ,066 &, 046 &, 025 \\
\hline Nederlands: overschot & 013 &, 453 &, 013 & ,461 \\
\hline Nederlands: tekort &, 026 & 178 &,- 006 & ,756 \\
\hline Wiskunde: eigen niveau &, 069 &, 000 &, 057 &, 004 \\
\hline Wiskunde: overschot &,- 011 &, 550 &, 007 & ,698 \\
\hline Wiskunde: tekort &,- 027 & 135 &,- 024 & ,194 \\
\hline Engels: eigen niveau &, 016 &, 442 &,- 010 &, 650 \\
\hline Engels: overschot &, 004 &, 813 &,- 020 & ,288 \\
\hline Engels: tekort &,- 006 & ,773 &,- 038 & ,063 \\
\hline Computervaardigheden: eigen niveau &,- 046 &, 020 &,- 034 & ,092 \\
\hline Computervaardigheden: overschot &, 001 & 965 &, 007 & ,696 \\
\hline Computervaardigheden: tekort &,- 010 &, 573 &,- 023 & ,219 \\
\hline Nauwkeurig werken: eigen niveau &,- 020 &, 347 &,- 023 & ,299 \\
\hline Nauwkeurig werken: overschot &, 019 & 285 &, 000 & ,988 \\
\hline Nauwkeurig werken: tekort &,- 040 &, 037 &,- 035 & ,071 \\
\hline Analytische vaardigheden: eigen niveau &, 072 &, 000 &, 055 & ,007 \\
\hline Analytische vaardigheden: overschot &,- 006 &, 713 &, 001 & ,967 \\
\hline Analytische vaardigheden: tekort &,- 019 &, 316 &,- 036 &, 055 \\
\hline
\end{tabular}

* gemiddeld van een viertal aspecten 
BIJLAGE III Volledige resultaten mbo

\begin{tabular}{|c|c|c|c|c|}
\hline & \multicolumn{2}{|c|}{ Voorbereiding } & \multicolumn{2}{|c|}{ Aansluiting } \\
\hline & Beta & Sign. & Beta & Sign. \\
\hline Constante & &, 000 & &, 000 \\
\hline leeftijd &,- 014 & 055 & ,029 &, 000 \\
\hline geslacht: vrouw &, 006 &, 463 &, 023 &, 002 \\
\hline Etniciteit: autochtoon & ref. & & ref. & \\
\hline Etniciteit: westerse allochtoon &,- 002 & 681 &,- 006 & ,283 \\
\hline Etnicitieti: niet-westerse allochtoon &,- 020 &, 001 &, 007 &, 226 \\
\hline Meetjaar: 2011 & ref. & & ref. & \\
\hline Meetjaar: 2012 &,- 006 &, 436 &, 005 &, 501 \\
\hline Meetjaar: 2013 &,- 044 &, 000 &,- 007 & ,416 \\
\hline Meetjaar: 2014 &,- 019 &, 012 &, 000 &, 990 \\
\hline \multicolumn{5}{|l|}{ MBO sector } \\
\hline Groen &,- 006 &, 400 &, 008 & ,208 \\
\hline Economie &,- 022 &, 005 &, 038 &, 000 \\
\hline Gezondheidszorg &, 052 &, 000 &, 042 &, 000 \\
\hline Gedrag \& Maatschappij &,- 040 &, 000 &, 007 & ,384 \\
\hline Techniek & ref. & & ref. & \\
\hline MBO leerweg: BOL &,- 075 &, 000 &,- 061 &, 000 \\
\hline $\mathrm{MBO}$ niveau $3 / 4$ &, 042 &, 000 &,- 020 &, 002 \\
\hline gemiddeld afstudeercijfer &, 024 &, 000 &, 022 &, 000 \\
\hline \multicolumn{5}{|l|}{ Domein werkzaam } \\
\hline Kerndomein & ref. & & ref. & \\
\hline horizontale mismatch &,- 068 &, 000 &,- 140 &, 000 \\
\hline verticale mismatch &,- 016 &, 010 &,- 010 & , 102 \\
\hline dubbele mismatch &,- 111 &, 000 &,- 248 &, 000 \\
\hline Carriereperspectieven in functie & ,175 &, 000 & , 142 &, 000 \\
\hline Tijdens opleiding ervaring bij werkgever &, 064 &, 000 & ,079 &, 000 \\
\hline \multicolumn{5}{|l|}{ Oordeel over mbo opleiding } \\
\hline voldoende getoets op inzicht &, 050 &, 000 &, 056 &, 000 \\
\hline hoeveelheid praktijk &, 034 &, 000 &, 045 &, 000 \\
\hline kwaliteit docenten &, 032 &, 000 &, 030 &, 000 \\
\hline voorlichting over beroepsmogelijkheden & ,159 &, 000 & ,104 &, 000 \\
\hline breedte mbo opleiding: te smal &,- 124 &, 000 &,- 096 &, 000 \\
\hline breedte mbo opleiding: te breed &, 017 &, 005 &,- 032 &, 000 \\
\hline selectiviteit mbo opleiding* &, 085 &, 000 &, 056 &, 000 \\
\hline
\end{tabular}


BIJLAGE III Volledige resultaten mbo

\begin{tabular}{|c|c|c|c|c|}
\hline & \multicolumn{2}{|c|}{ Voorbereiding } & \multicolumn{2}{|c|}{ Aansluiting } \\
\hline & Beta & Sign. & Beta & Sign. \\
\hline \multicolumn{5}{|l|}{ Competenties } \\
\hline vakkennis: eigen niveau &, 040 &, 000 & , 109 &, 000 \\
\hline vakkennis: tekort &, 014 &, 071 &,- 024 &, 002 \\
\hline vakkennis: overschot &,- 028 &, 000 &,- 060 &, 000 \\
\hline persoonlijkheid: eigen niveau &, 027 &, 002 &,- 008 & ,392 \\
\hline persoonlijkheid: tekort &, 001 &, 892 &,- 030 &, 000 \\
\hline persoonlijkheid: overschot &,- 022 &, 003 &,- 028 &, 000 \\
\hline basis generieke competenties: eigen niveau & 041 &, 000 &,- 013 &, 091 \\
\hline basis generieke competenties: tekort &, 006 & ,392 &,- 015 &, 039 \\
\hline basis generieke competenties: overschot &, 002 & ,795 &,- 010 &, 153 \\
\hline geavanceerde generieke competenties: eigen niveau &, 005 & ,646 &,- 020 &, 038 \\
\hline geavanceerde generieke competenties: tekort &, 000 & ,999 &,- 025 & ,002 \\
\hline geavanceerde generieke competenties: overschot &, 004 &, 588 &,- 029 &, 000 \\
\hline
\end{tabular}


BIJLAGE IV Volledige resultaten hbo

\begin{tabular}{|c|c|c|c|c|}
\hline & \multicolumn{2}{|c|}{ Voorbereiding } & \multicolumn{2}{|c|}{ Aansluiting } \\
\hline & Beta & Sign. & Beta & Sign. \\
\hline Constante & &, 000 & &, 000 \\
\hline leeftijd &,- 010 & , 122 &,- 006 &, 336 \\
\hline geslacht: vrouw &,- 036 &, 000 &, 004 &, 540 \\
\hline Etniciteit: niet-westerse allochtoon & ref, & & ref. & \\
\hline Etniciteit: westerse allochtoon &, 026 &, 002 &, 026 &, 002 \\
\hline Etnicitieti: autochtoon &, 027 &, 002 &, 034 &, 000 \\
\hline Meetjaar: 2013 & ref. & & ref. & \\
\hline Meetjaar: 2014 &,- 013 &, 040 &,- 005 & ,446 \\
\hline \multicolumn{5}{|l|}{ HBO Sector } \\
\hline landbouw &, 000 & 966 &,- 025 &, 000 \\
\hline onderwijs &,- 021 &, 005 & ,031 &, 000 \\
\hline techniek &, 035 &, 000 &,- 013 & ,071 \\
\hline gezondheidszorg &,- 049 &, 000 & ,018 & 011 \\
\hline gedrag \& maatschappij &,- 084 &, 000 &,- 015 &, 032 \\
\hline economie & ref. & & ref. & \\
\hline gemiddeld afstudeercijfer &, 022 &, 001 &, 031 &, 000 \\
\hline \multicolumn{5}{|l|}{ Domein werkzaam } \\
\hline Kerndomein & ref. & & ref. & \\
\hline horizontale mismatch &,- 069 &, 000 &,- 170 &, 000 \\
\hline verticale mismatch &,- 028 &, 000 &,- 065 &, 000 \\
\hline dubbele mismatch &,- 162 &, 000 &,- 371 & 0,000 \\
\hline Carriereperspectieven in functie & 137 &, 000 & ,158 &, 000 \\
\hline \multicolumn{5}{|l|}{ Oordeel hbo opleiding } \\
\hline breedte hbo opleiding: te smal &,- 082 &, 000 &,- 055 &, 000 \\
\hline breedte hbo opleiding: te breed &,- 083 &, 000 &,- 056 &, 000 \\
\hline opleiding was uitdagen & 114 &, 000 & ,061 &, 000 \\
\hline inbedding praktijkgericht onderzoek & , 100 &, 000 &, 052 &, 000 \\
\hline voorlichting beroepsmogelijkheden & ,205 &, 000 &, 079 &, 000 \\
\hline kwaliteit docenten & ,102 &, 000 &, 052 &, 000 \\
\hline \multicolumn{5}{|l|}{ Competenties } \\
\hline eigen vakkennis: eigen niveau & ,081 &, 000 & ,142 &, 000 \\
\hline eigen vakkennis: overschot &,- 042 &, 000 &,- 117 &, 000 \\
\hline
\end{tabular}


BIJLAGE IV Volledige resultaten hbo

\begin{tabular}{|l|r|r|r|r|}
\hline & \multicolumn{2}{|c|}{ Voorbereiding } & \multicolumn{3}{c|}{ Aansluiting } \\
& Beta & \multicolumn{1}{c|}{ Sign. } & Beta & \multicolumn{2}{c|}{ Sign. } \\
\hline eigen vakkennis: tekort &,- 005 &, 582 &, 000 &, 997 \\
\hline andere vakkennis: eigen niveau &,- 024 &, 002 &,- 024 &, 001 \\
\hline andere vakkennis: overschot &, 002 &, 797 &,- 009 &, 212 \\
\hline andere vakkennis: tekort &,- 011 &, 142 &,- 030 &, 000 \\
\hline academische competenties: eigen niveau &,- 017 &, 085 &,- 050 &, 000 \\
\hline academische competenties: overschot &, 015 &, 111 &, 021 &, 015 \\
\hline academische competenties: tekort &, 003 &, 759 &,- 008 &, 379 \\
\hline management: eigen niveau &, 035 &, 000 &, 043 &, 000 \\
\hline management: overschot &,- 009 &, 326 &,- 024 &, 004 \\
\hline management: tekort &,- 019 &, 029 &,- 009 &, 267 \\
\hline
\end{tabular}


BIJLAGE V Controle variabelen voor Multinomiale analyses (zie ook voor meer detail, Bijlage 1 tot en met Bijlage IV)

$$
\begin{array}{ll}
\multicolumn{2}{c}{\text { Persoonlijke kenmerken }} \\
\text { o } & \text { Leeftijd } \\
\text { o } & \text { Geslacht } \\
\text { o } & \text { Etniciteit }
\end{array}
$$

\section{Meetjaar}

\section{Gevolgde opleiding}

o VMBO: leerweg en sector

o AVO: HAVO, VWO en profiel

- MBO: leerweg, niveau en sector

o HBO: sector

Vervolgopleiding (VMBO, AVO)

- $\quad$ Niveau, leerweg en verwante doorstroom

o Situatie in vervolgopleiding op moment van enquête: nog bezig / gestopt / diploma behaald

Oordelen over gevolgde opleiding

Competenties

Tekorten en overschotten aan competenties 
